\title{
Impact of the Antitrust Laws on the Commercialization of Solar Heating and Cooling
}

Jill Gross
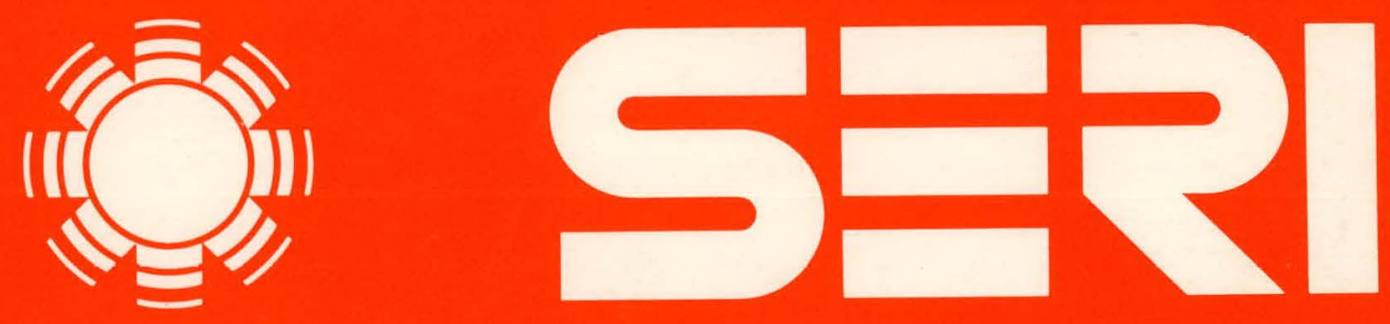

Solar Energy Research Institute

A Division of Midwest Research Institute

1536 Cole Boulevard

Golden, Colorado 80401

Operated for the U.S. Department of Energy under Contract No. EG-77-C-01-4042

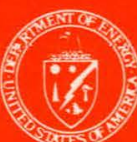




\section{DISCLAIMER}

This report was prepared as an account of work sponsored by an agency of the United States Government. Neither the United States Government nor any agency Thereof, nor any of their employees, makes any warranty, express or implied, or assumes any legal liability or responsibility for the accuracy, completeness, or usefulness of any information, apparatus, product, or process disclosed, or represents that its use would not infringe privately owned rights. Reference herein to any specific commercial product, process, or service by trade name, trademark, manufacturer, or otherwise does not necessarily constitute or imply its endorsement, recommendation, or favoring by the United States Government or any agency thereof. The views and opinions of authors expressed herein do not necessarily state or reflect those of the United States Government or any agency thereof. 


\section{DISCLAIMER}

Portions of this document may be illegible in electronic image products. Images are produced from the best available original document. 
Printed in the United States of America Available from:

National Technical Information Service

U.S. Department of Commerce

5285 Port Royal Road

Springfield, VA 22161

Price:

Microfiche $\$ 3.00$

Printed Copy $\$ 5.25$

This report was prepared as an account of work sponsored by the United States Government. Neither the United States nor the United States Department of Energy, nor any of their employees, nor any of their contractors, subcontractors, or their employees, makes any warranty, express or implied, or assumes any legal liability or responsibility for the accuracy, completeness or usefulness of any information, apparatus, product or process disclosed, or represents that its use would not infringe privately owned rights. 
SERI /TR-62-272

UC CATEGORY: UC-59

IMPACT OF THE ANTITRUST LAWS

ON THE COMMERCIALIZATION OF

SOLAR HEATING AND COOLING

JILL GROSS

JUNE 1979

\section{Solar Energy Research Institute}

1536 Cole Boulevard

Golden, Colorado 80401

A Division of Midwest Research Institute

Prepared for the

U.S. Department of Energy

ContractNo. EG.77.C.01·4042 


\section{FOREWORD}

This paper on the impact of the antitrust laws on the commercialization of solar heating and cooling, was prepared by the Solar Energy Research Institute (SERI) to fulfill, in part, SERI's solar information dissemination function. This paper is part of the Market Development Branch Law Program, which is in turn part of the overall program of the Technology Commercialization Division.

This is the first of eight 1978 Summer Law Intern Papers sponsored by the SERI Law. Program. The other seven address (1) licensing arrangements and the development of the solar energy industry, (2) problems in the administration of state solar legislation, (3) legal and institutional implications of providing financial incentives to encourage the development of solar energy technologies, (4) legal considerations in the development and implementation of biomass energy technologies, (5) state approaches to solar energy incentives, (6) land-use barriers and incentives to the use of solar energy, and (7) utility rates and service policies as potential barriers to the market penetration of decentralized solar technologies. These eight studies are meant to raise and discuss the primary legal issues that are, or will be, generated by the commercialization of solar technologies.

The author of this paper, Jill Gross, was a student at the University of Denver Law School while she was participating in the 1978 Summer Law Intern Program. In late 1979, she will begin practicing as an attorney with the Antitrust Division of the United States Department of Justice.

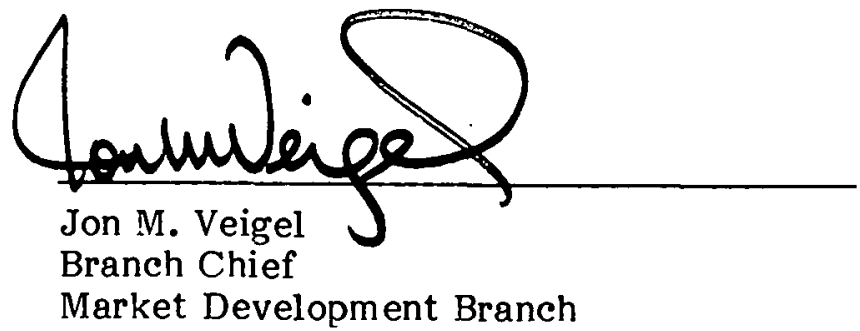

Approved for:

SOLAR ENERGY RESEARCH INSTITUTE

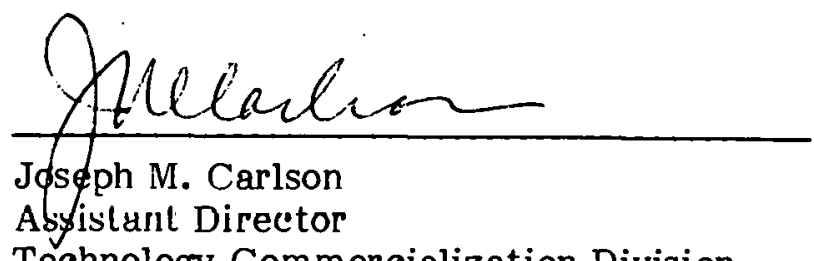

Technology Commercialization Division 
Many energy industry observers and solar equipment producers view the commercialization of solar technologies as an opportunity to undermine the dominance now enjoyed by energy companies and electric utilities. Whether their hopes will be realized depends on Congress' posture towards interenergy diversification (which is currently permissive), DOE's spending practices (which have, in the past, been relatively insensitive to competitive consequences), and ultimately, the Supreme Court's willingness to aggressively enforce the antitrust laws (which is not unlikely, given recent holdings).

Notwithstanding the legislative and administrative branches' tacit compliance with entrenched firms' involvement in the various solar energy submarkets, injured business persons and consumers (as well as the Department of Justice and the Federal Trade Commission) have the opportunity to force the controversy onto the judiciary by bringing suit under the antitrust laws against companies allegedly displaying anticompetitive market practices.

The interchangeability between end uses of renewable and nonrenewable energy resources creates opportunities and motives for market manipulation. Consequently, the potential of energy firms for facilitating solar technology development (due to technological knowledge, managerial expertise and capital resources) must be weighed against the possibility that their involvement will, in the long run, retard development.

Even assuming there are immediate benefits to be gained from firms' efforts to commercialize solar, long-term impacts on the structure of the emerging solar industry must be considered. The solar industry is presently dominated by small, undercapitalized businesses that may seek to combine with other such businesses in order to take advantage of obvious economies of scale. The antitrust laws will have an impact on these small business mergers.

Inasmuch as organizational diversity is an economic and social value, the antitrust laws may be enforced to prevent large firms from dominating the solar industry where their involvement tends to substantially lessen competition or to create a monopoly.

Utilities' regulated monopoly status complicates application of the antitrust laws. Recent Supreme Court cases have rejected the notion that economic regulation of an industry precludes enforcement of the antitrust laws. The extent to which utilities can now safely enter unregulated markets is unclear. However, the trend is unmistakably towards stricter scrutiny of regulated entities market practices. 


\section{TABLE OF CONTENTS}

$\underline{\text { Page }}$

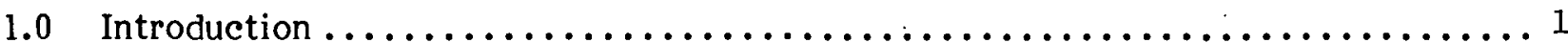

2.0 Competition and Antitrust Law $\ldots \ldots \ldots \ldots \ldots \ldots \ldots \ldots \ldots \ldots \ldots \ldots \ldots$

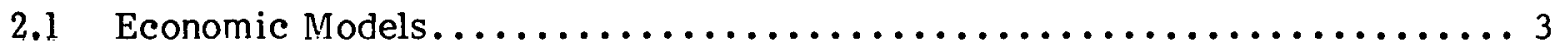

2.2 Overview of the Legal Framework....................... 4

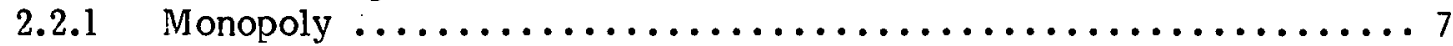

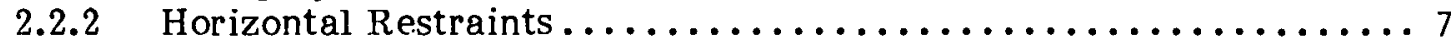

2.2.3 Arrangements Between Suppliers and Customers in

2.2.4 Mergers..................................... 8

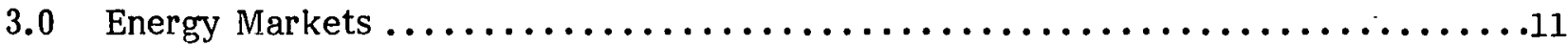

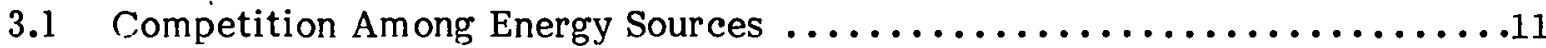

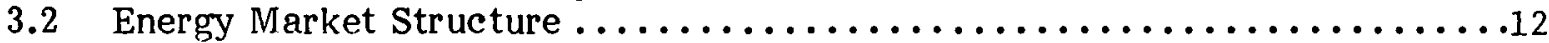

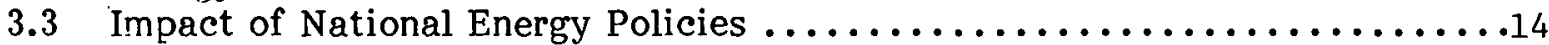

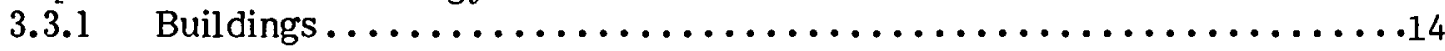

3.3.2 Agricultural and Industrial.........................

4.0 Solar Heating and Cooling: An Antitrust Analysis $\ldots \ldots \ldots \ldots \ldots \ldots \ldots \ldots \ldots \ldots$

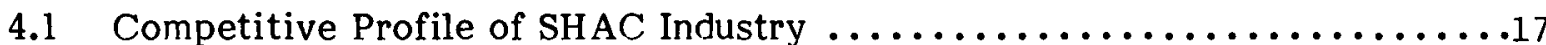

4.2 Competitive Impact of Federal Spending $\ldots \ldots \ldots \ldots \ldots \ldots \ldots \ldots \ldots \ldots$

4.3 Competitive Impact of Energy Company Involvement in

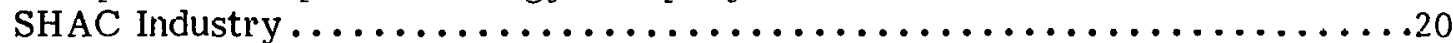

4.3.1 Monopolization Under the Sherman Act $\ldots \ldots \ldots \ldots \ldots \ldots \ldots \ldots$

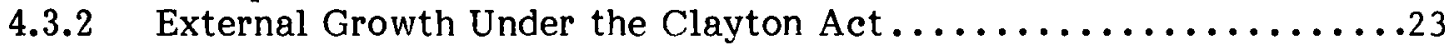

4.4 Competitive Impact of Utility Company Involvement in

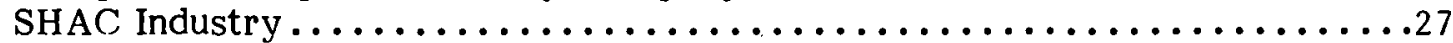

4.4.1 Interaction Between Regulation and Antltrust

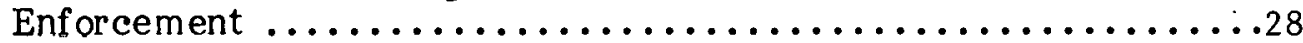

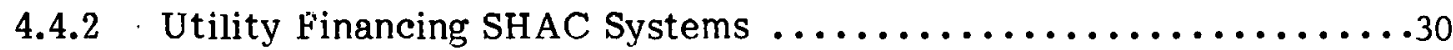

4.4 .3 Utility Servicing and Repairing SHAC Systems $\ldots \ldots \ldots \ldots \ldots \ldots \ldots . \ldots \ldots$

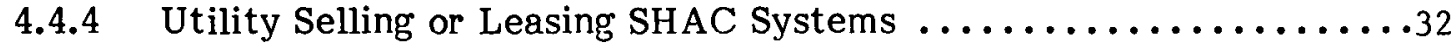

4.4.5 Utility Nonentry into the SHAC Market ......................

4.5 Competitive Impact of Small Business Involvement in

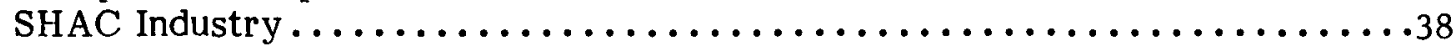

4.5.1 Pro-Small Business Legislation ............................

4.5 .2 Joint Research Activities ..........................

4.5.3 Miscellaneous Horizontal Arrangements Among

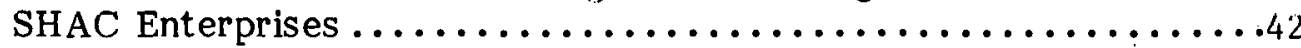

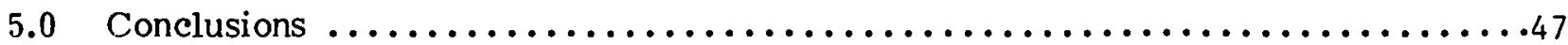

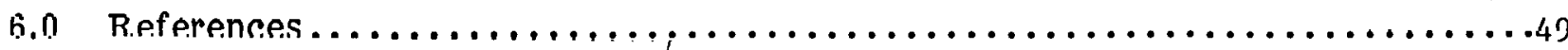




\section{SECTION 1.0}

\section{INTRODUCTION}

Successful commercialization of solar heating and cooling technologies ultimately depends on the development of a healthy, competitive solar industry. Solar development will be heavily dependent on governmental policies regulating competition in our economy in general, and in the emerging solar industry in particular. This paper will examine existing antitrust laws as they affect economic activity in the solar industry, and the need to shape future antitrust policies so as to promote the development of a healthy, competitive solar market.

Although most Americans regularly consume energy for heating and cooling in large amounts, they generally do not directly use the resources from which energy is generated. Instead, primary energy resources-oil, coal, natural gas, and uranium-are converted into useful forms of energy such as electricity. This energy is, in turn, marketed to the ultimate energy users.

Heating and cooling with solar energy is unusual because, in many instances, the requisite energy may be harnessed and applied to the actual heating and cooling without the typical intervention of a third party energy converter. Equipment is now being perfected that will use the sun directly to heat buildings. Other equipment will convert primary solar energy into secondary forms of energy, such as electricity, which can drive on-site heating or cooling systems. Flat-plate collectors, for example, use direct insolation to provide for the heating and cooling of buildings and water. Similarly, photovoltaic processes convert the sun's rays into electricity. These developing technologies will enable consumers to satisfy their energy requirements by purchasing equipment on a onetime basis, thus relying on the sun as a primary fuel source without relying on power companies.

This paper focuses on the commercialization of solar heating and cooling (SHAC) of air and water. To date, the technology behind these SHAC processes is better suited to individual use than to any other solar energy applications. Although national energy goals call for SHAC to become a vital energy submarket [1], the solar industry is still in its infancy and no one can project with certainty how, and by whom, solar energy equipment will be marketed.

The antitrust laws are traditionally enforced to promote competitive market structures and conduct. Because the solar industry is so young and ultimately must be assessed in the context of the energy industry as a whole, this paper will emphasize structural aspects of the energy market and submarkets rather than market conduct; necessary factual data on market structure is presently available and the energy market structure that is peculiar to this industry has a direct impact on future market behavior and performance. Market conduct is less useful because data on specific market practices in the SHAC industry are sparse, and also because much analysis of market conduct (e.g., regarding price fixing) applies regardless of the specific market context. Therefore, market conduct will be discussed only to the extent that certain practices either contribute to the structural development of a market (e.g., mergers) or require special attention because the solar industry is in its infancy (e.g., patent acquisitions). 
SEP1 


\section{SECTION 2.0}

\section{COMPETITION AND ANTITRUST LAW}

Fostering and maintaining competition is the fundamental economic policy of the United States [2]. This policy is premised on economic theory that views competition in a perfect market setting. It encourages optimum resource allocation, a socially desirable goal [3]. The pressures of competition will force prices down to the cost of efficient production plus a reasonable return on investment. In a monopolized market, the absence of competitive pressures will allow prices to rise to include "monopoly profits" and costs of inefficient operation. To the extent that a monopolized market allows inefficient operation to persist and even thrive, or permits the retention of unreasonable profits, excessive resources are being devoted to satisfy a particular societal demand at the expense of other societal needs.

Of course, the ideal operation of a perfectly competitive market requires conditions that are rarely met in the real world. It is questionable how effectively conditions approaching "perfect competition" result in efficient resource allocation. However, relatively competitive market structures also reflect society's attitude that profits should bear a reasonable relationship to costs and risks, and should be no greater than necessary to call forth the investment that yields them. Furthermore, the policy of maintaining competition, apart from economic theories regarding resource allocation, is a logical extension of certain traditional populist values: decentralized economic power, a wide range of entrepreneurial opportunities, and a preference for the small over the large.

Because unchecked markets have of ten led to aggregation of economic power in originally efficient enterprises that eventually dominate and destroy their competitors, Congress has enacted a series of federal antitrust laws. The basic statutes are the Sherman Act [4], the Clayton Act [5], and the Federal Trade Commission Act (FTCA) [6]. These statutes were intended to enhance competition by prohibiting unfair or restrictive trade practices and undue concentrations of market power. The operative language of these statutes is generally broad and vaguely phrased. Of necessity, courts faced with interpreting this sweeping general language have determined the meaning and limits of the antitrust laws on a case by case basis, exercising broad discretion. A possible limitation on judicial discretion is the statutes' applicability only to interstate commerce. However, contemporary constitutional doctrine excludes very little commercial activity from its definition of "interstate" [7]. Even local anticompetitive acts tend to have some effect on interstate commerce [8]. The preceding three statutes will be the center of most antitrust issues regarding SHAC commercialization efforts.

\subsection{ECONOMIC MODELS [9]}

Although the common law of antitrust has developed some "black letter" legal principles, the bulk of antitrust analysis involves a review of competitive or anticompetitive factors in the context of a given industry, market, commercial relationship, or practice in terms of a series of economic models from which the courts seem to derive their decisions. A discussion of the law must, therefore, be built upon an awareness of the underlying economic models relied on by the courts.

According to economic theory on which federal antitrust legislation is based, the social benefits that tend to flow from a competitive market's performance are (1) pricing that 
is related to costs and is responsive to changes in supply and demand, (2) efficient allocation and utilization of resources, (3) technology that is efficient and innovative, and (4) logically restricted market entry and exit. Although the ultimate social concern is economic performance, legal norms focus more on market structure and conduct. In most cases, courts are ill-equipped to evaluate the overall actual versus potential performance of an industry. Economists, on the other hand, have studied the relationships between various market structures and behaviors and overall market performances, and have formulated models against which a given market may be judged. Judicial opinions applying the antitrust laws implicitly subscribe to the conclusions drawn from such economic models.

Economists have learned that if only one firm is supplying the entire market demand, that firm can alter its own output, produce less, charge a higher price, and earn a larger gross profit. If other firms attempt to compete with the monopolist by offering their products at the lower price, the monopolist can easily prevent them from entering the market by temporarily reverting to its original output/pricing scheme to combat the competition. Thus, a monopolist has the market power to control prices and exclude competitors.

In contrast to monopoly, a multi-firm or competitively structured market encourages competitive conduct. A firm that behaves inefficiently, or raises prices unreasonably (as suggested in the preceding example) would lose money; rather than paying a higher price, consumers could choose fairly priced competing products. To achieve higher profits, a firm facing competition must take the market price as given and vary its own output and input factors. A genuinely competitive structure precludes market manipulation, and forces each firm to perform more efficiently and economically.

Oligopoly is a third structural model wherein no single firm possesses sufficient power to be considered a monopoly, but where the conduct and performance of a handful of firms approaches that of a monopolist. Each firm is conscious of the others' presence and behavior, and each is sensitive to rival output and pricing decisions. The interdependence that exists in the automobile industry is a good example of oligopoly conditions. Profitable moves are matched quickly (witness the current trend to smaller cars), while unsuccessful product variations attributable to a particular firm are not readily forgotten by the public (witness the Edsel). Thus, the risks inherent in nonconformity tend to make oligopolists conservative. Because price reductions are easily and quickly matched, while price increases (if unmatched) are cisasterous, oligopolists tend to avoid price changes except in response to a price leader's fluctuations. The oligopolistic structure, therefore, encourages firms to parallel rival behavior rather than respond to changes in technology or consumer preferences.

Although precise predictions regarding the market performance of an oligopolistic industry are difficult to make, it has been generally accepted, as a basis for federal antitrust policy, that

... the smaller the number of firms in an industry-at least where that number is very small or where a very small number is responsible for the overwhelming share of the industry's output-the greater the likelihood that the behavior of the industry will depart from the competitive norm. [10]

\subsection{OVER VIEW OF THE LEGAL FRAMEWORK [1 1$]$}

Although each of the three major federal antitrust statutes [12] is directed at a different aspect of anticompetitive activity, as a practical matter there is a large degree of 
overlap in their coverage that allows for litigation to be pursued under more than one statutory theory.

The Sherman Act is the basic'statute that condemns restraints or monopolizations of trade or commerce [13]. The Clayton Act covers a variety of more specific practices. For purposes of this article, the most important proscriptions forbid sales agreements conditioned on the buyer's not dealing with other suppliers in competition with the seller, and certain corporate mergers where the effect "may be to substantially lessen competition or tend to create a monopoly" [14]. The Clayton Act is thus applicable to incipient monopolies and trade restraints outside the scope of the Sherman Act [15]. Section 5 of the FTCA declares unlawful "unfair methods of competition" and "unfair or deceptive acts or practices in commerce" [16]. In general, any practice that violates the policies underlying the Sherman Act or the Clayton Act is amenable to prosecution under the FTCA [17]. The breadth of the FTCA is mitigated by its party limitation-only the Federal Trade Commission (FTC) may pursue an action under the Act [18]. By contrast, claims under the Sherman or Clayton Acts can be brought by private litigants [19], the Antitrust Division of the Department of Justice (DOJ) [20], the FTC [21], and the state attorneys general [22].

The federal antitrust laws apply only to "interstate commerce," a term that raises difficult questions of federal constitutional power and statutory construction. Contemporary constitutional doctrine includes in its definition of commerce any "occupation, employment, or business . . . carried on for the purpose of profit or gain" [23]. Activity that constitutes "commerce" within the meaning of the Commerce Clause [24] and is also within the purview of a given antitrust statute, is properly governed by federal law. Because all three statutes contain a reference to "commerce," any statutory limitation on the types of commercial activities subject to the jurisdiction of the antitrust laws should be traceable to a specific congressional expression of exclusion.

The Sherman Act's concern with restraints or monopolization of "trade or commerce" [25], has been interpreted as going "to the utmost extent of [Congress'] constitutional power" [26]. Hence, most activities that are "commerce" in the constitutional sense constitute "trade or commerce" within the meaning of that Act [27]. Provisions of the Clayton Act and the FTCA refer more narrowly to persons or acts "in commerce" or "in the course of such commerce" [28]. This language does not limit the types of activities that constitute commerce [29]. Rather, it has been interpreted as requiring a more specific interstate nexus than is called for by the Sherman Act's reference to "trade or commerce among the several states" [30]."

The Commerce Clause empowers Congress to "regulate commerce . . . among the several states" [31]. Under Supreme Court interpretations of the Clause, federal power is not limited to commerce that actually moves across state lines; it includes also activities that "affect" interstate commerce, although such activities, taken alone, might be considered local [32]. Given contemporary economic conditions, most local business activities have some repercussions upon commerce beyond state lines. The Sherman Act, which is applicable to the limits of Congress' constitutional authority, may therefore be applied to any commercial activities in the flow of interstate commerce [33] or materially affecting interstate commerce [34]. On the other hand, purely intrastate commerce, notwithstanding its potential effect on interstate commerce, is beyond the reach of the Clayton Act and the FTCA [35].

Antitrust law is significantly devoid of defined elements necessary to state causes of action. Courts normally find commercial activities offensive to antitrust policies where there is a demonstrated or potential negative impact on competition. Antitrust law is, 
therefore, best understood as an analytic approach to anticompetitive activities that is resting on a set of values and principles. As the courts gain sufficient exposure to a particular practice, less discretionary legal criteria are formulated for judging future fact patterns resembling that practice. Characterization of the commercial activity then becomes crucial and is of ten dispositive of the case.

Accordingly, certain agreements or practices are treated as per se illegal "because of their pernicious effect on competition and lack of any redeeming virtue" [36]. For example, in United States v. Socony-Vacuum Oil Co., the Court declared that "pricefixing combinations are illegal per se; they are not evaluated in terms of their purpose, aim or effect... [because a] ny combination which tampers with price is engaged in an unlawful activity" [37]. Thus, once an arrangement is judicially characterized as a "price-fixing" combination, it is illegal. Prolonged inquiry into the resulting harm or business reasons for the conduct is foreclosed.

Most types of antitrust violations do not fall into the per se category. Rather, the defendant's activities are judged by a "rule of reason." Justice Rrandeis' classic statement of the rule is worth quoting at length:

[T] he legality of an agreement or regulation cannot be determined by so simple a test, as whcther it restrains competition. Every agreement concerning trade, every regulation of trade, restrains. To bind, to restrain, is of their very essence. The true test of legality is whether the restraint imposed is such as merely regulates and perhaps therehy promotes competition or whether it is such as may suppress or even destroy competition. To determine that question the court must ordinarily consider the facts peculiar to the business ... i its condition before and after the restraint was imposed, the nature of the restraint, and its effect, actual and probable. The history of the restraint, the evil believed to exist, the reason for adopting the particular remedy, the purpose or end sought to be attained, are all relevant facts. This is not because a good intention will save an achieved objectionable regulation or the reverse; but because knowledge of intent may help the court to interpret facts and to predict consequences. [38]

Thus, the rule of reason is a standard that asks the court to identify the practice involved, determine the purposes and likely competitive (or anticompetitive) effects of the practice, and decide whether, on balance, the activity substantially impedes competition. In some situations, social harms and benefits unrelated to competition may also influence the balancing decision.

Antitrust litigation typically involves complex fact patterns that require protracted lieurings and extensive expert testimony in order to be resolved. The two modes of analysis highlighted previously. (activities declared per se illegal versus arrangements judged by the rule of reason) represent extremes between which the courts fluctuate, depending on the facts of each case, the political climate, the judges' personalities and abilities, and other nonlegal factors. Additionally, each category of unlawful activity has emerged from a line of precedents that provide specific criteria against which a given situation may be judged. The varieties described in the following paragraphs are not intended to exhaust the list of possible antitrust violations. Rather, the presentation is intended to highlight major categories of commercial activities and to emphasize the legal tools necessary for antitrust analysis. 


\subsubsection{Monopoly}

Section 2 of the Sherman Act (Sherman \$2) condemns monopolization, attempts to monopolize, and conspiracies to monopolize [39]. Generally, a firm violates Sherman $\$ 2$ only if it possesses a significant amount of power in the relevant market, and has acquired or maintained that power through improper means. Thus, the mere fact that a firm occupies a monopoly position is not in and of itself illegal. Contemporary antitrust doctrine requires a showing of "dominance plus" (i.e., greater market power than any other firm and participation in a practice which enhances or increases that power). A firm's power is determined by defining the relevant market, in product and geographic terms, and assessing the firm's share of that market, typically by comparing the relative sales of the defendant and its competitors [40]. But it is a firm's pattern of acquiring or maintaining a dominant market position that violates Sherman \$2, as where either (1) the power was obtained as a result of participation in an unreasonable restraint of trade, (2) the firm has the power to exclude competitors and intends to or has exercised it, or (3) the firm has acquired an overwhelming share of the market and its business practices are used to maintain that position [41].

\subsubsection{Horizontal Restraints [42]}

Collaboration among competitors is a classic antitrust concern [43]. In many cases, competition in the relevant market is lessened and the collaborators secure an opportunity to reap monopoly profits.

Section 1 of the Sherman Act (Sherman \$1) prohibits contracts, combinations, or conspiracies in restraint of trade [44], and has been successfully invoked against competitors that have horizontally agreed to manipulate the market. Because effect on competition is the ultimate concern of the legislation, proof of explicit mutual assent is not necessarily a prerequisite to a judicial finding of unlawfulness under Sherman \$l. Courts have inferred a conspiratorial purpose from circumstantial evidence of concerted horizontal actions [45]. Such evidence can trigger a presumption of anticompetitive activity. The defendants can rebut this presumption with evidence to justify the challenged activity, where exchanging information will have a long-term benefit on the industry. Absent such rebuttal, the evidence of concerted action will likely support a finding of illegality [46]. Actions such as price-fixing schemes [47], data dissemination [48], concerted refusals to deal (group boycotts) [49], territorial allocations [50], and various other concerted actions among competitors [51] tend to fall within the Sherman $\$ 1$ prohibition. In fact, many horizontal restraints have been judicially labeled per se unlawful [52] because:

[s] uch close cooperation between many [competing] persons, firms, and corporations controlling a large volume of interstate commerce ... [is] inconsistent with that free and unrestricted trade which the statute contemplates shall be maintained .... This is not the conduct of competitors but is ... clearly that of men united in an agreement, express or implied, to act together and pursue a common purpose under a common guide. [53]

Notwithstanding this statement by the Supreme Court, a more useful generalization is that collaboration among competitors is likely to violate the Sherman Act if (1) anticompetitive market effect is either proven or inferable from the collaborators' market power, or (2) the combination's underlying purpose and/or methodology is unreasonable or anticompetitive. 


\subsubsection{Arrangements Between Suppliers and Customers in Restraint of Trade (Vertical} Restraints) [54]

Vertical restraints are of ten imposed for legitimate business reasons and are, therefore, treated more liberally than horizontal restraints. If a manufacturer uses a location restriction [55] to induce the retailer to follow the manufacturer's policy toward service and repair facilities, current antitrust policies might tolerate the arrangement because it allows the manufacturer to achieve certain efficiencies in the distribution of his products and consequently promotes interbrand competition [56].

Nonetheless, vertical restraints on the distribution of a product are an antitrust concern because competition may be foreclosed in the relevant market. Per se rules and set principles have little applicability in this area; extensive market analyses are hard to avoid. "Garden varieties" of arrangements between suppliers and customers have been identified in the case law for different treatment depending on the potential harms associated with the named practice.

Consignment and distribution through agents, and territorial and customer limitations restrict the distribution of products so as to raise serious issues under Sherman \$1 [57] or $\$ 2$ [58]. However, such restraints are not per se illegal [59]. Under a rule of reason analysis, a new market entrant may be given leeway to engage in restrictive practices for a reasonable amount of time so as to enable the entrant to establish a viable market position [60]. In each vertical restraint case judged by a rule of reason, the court will consider whether the restraint has been imposed for an excessive amount of time; whether coercion is used to enforce the practice; whether there is a market justification for the restraint; the type of industry involved; and the degree of concentration existing in the relevant market, including the number of competitors in such market.

A supplier's refusal to deal with certain customers is a form of restricted distribution that requires separate attention. Such a practice, in and of itself, can be a legitimate exercise of freedom of trade promoted by the antitrust laws' policy [61]. However, where a manufacturer attempts to impose restrictions on retailers or wholesalers through methods such as coercion to assure compliance, or requirements calling for cooperation among customers, such imposition is suspect under Sherman \$1 [62]. Furthermore, a dominant entity's refusal to deal may be treated as an attempt to monopolize [63] .

\subsubsection{Mergers}

For purposes of antitrust law, a merger is any corporate arrangement that results in a permanent union of two previously separate legal entities. The term includes all types of fundamental structural changes known to corporate law (e.g., consolidations and acquisitions). Each merger replaces previously separate decision making with some form of unified decision making on behalf of the merged entities.

Mergers may beneficially effect the market through the achievement of cost savings via technological efficiencies, distribution. economies, and efficient resource use. However, particularly when one of the merging entities is large, these benefits can be outweighed by a potentially less-competitive market structure as a result of the merger.

Section 7 of the Clayton Act (Clayton \$7) is directly aimed at the merger problem, and prohibits "any stock or asset acquisition whose effect may be to substantially lessen competition or tend to create a monopoly in any line of commerce in any section of the 
country" [64]. Under Clayton $\$ 7$, courts must therefore predict competitive effects of a challenged merger. Mergers are particularly vulnerable to attack where the resulting market structure threatens domination by large entities so that opportunities for future entry are foreclosed. The elimination of potential competitors that did not enter the market because of the merger, is a major focus of attack in cases currently arising under Clayton \$7 [65].

As firms become more diversified and more integrated, merger analysis becomes less confined to categorical inquiries. Antitrust merger cases of ten reflect three basic categories of mergers: vertical, horizontal, and conglomerate.

In a vertical merger case, the court's analysis starts with a definition of the relevant market, and a determination of the percentage share of the customer or supply market that is being foreclosed. If the market is concentrated and the merger forecloses a substantial portion, a presumption that competition may be lessened is likely [66]. Even if the share of the market foreclosed is not significant, a trend toward vertical integration in the industry can be probative of the merger's future competitive effects [67]. The linkage between upstream and downstream portions of the market can threaten the remaining unintegrated firms; they may be denied access to potential customers and/or supplies, and future entry into the industry may become feasible only for integrated entities. Because cooperation among vertical entities may produce desirable market efficiencies, judicial attitudes toward vertical mergers generally parallel the lenient treatment accorded vertical restraints. In both situations, the strictest scrutiny is reserved for entities which are dominant in their own industries, and industries already trending toward concentration or integration.

Antitrust policies toward horizontal mergers are generally harsher than in cases of vertical merger, and may be traced to a basic distaste for collaboration among competitors. Because some lessening of actual or potential competition between the firms is inevitable, horizontal mergers between significant market entities are almost presumptively violative of the antitrust laws.

Cases litigated under the Sherman Act, prior to the passage of the Clayton Act in 1914, held all challenged mergers between potential competitors per se unlawful [68]. The present judicial attitude represents a partial retreat from these early per se rulings. If the horizontal merger would produce a firm controlling an undue share of the market and would increase concentration significantly, and absent evidence to rebut the presumption of anticompetitive effects, a violation of Clayton $\$ 7$ is likely [69]. Although, in theory, this "market share" analysis need not end the inquiry, it is virtually impossible to successfully demonstrate that a merger yielding control of an undue market share and significantly increasing competition would not have a tendency to lessen competition, as prohibited by Clayton $\$ 7$ [70]. Even relatively modest increases in concentration, especially in an industry where there is an observable trend toward concentration, have been enough to establish a prima facie case of illegality [71].

Market extension mergers fall into a hybrid category somewhere between horizontal and conglomerate mergers. If a manufacturer of toothpaste and toothbrushes acquires a firm that manufactures dental floss, the union is called a product extension merger because the products may be distributed to the same customers through the same channels, even though they have different end uses. Similarly, if a distributor of beer confined to the southwest region acquires a distributor of the same product confined to the southeast region, the reference is to a geographic extension merger. 
Numerous mergers fall into the market extension category, and they require a more complex analysis than the prima facie market share test for mergers among direct competitors. Concentration and market shares must be addressed in more than one relevant market. Even if concentration levels are unchanged, there is an increased risk of collusion. Competitive injury to the acquired firms' market may result from the loss of the acquiring firm as a potential competitor. Therefore, the courts are particularly sensitive to the possibility that the acquiring firm has the ability to enter the market on its own (entry de novo), through internal expansion, or by acquiring a fledgling firm (toehold acquisition) [72]. Entry by internal expansion or toehold acquisition is of ten considered a less anticompetitive alternative to the merger at bar, and where feasible, these alternatives may lead a court to block an entry by merger [73].

A conglomerate merger is a union between firms operating in defined markets that are unrelated horizontally or vertically. In such mergers, the traditional market share analysis may not be an effective barometer of the merger's anticompetitive effects. As in cases of market extension mergers, judicial notions of potential competition and future entry play an important role in application of the antitrust laws.

Conglomerate mergers can also present a unique threat to competition because of the opportunity for reciprocity which may create protected markets. If a large food processor and distributor acquires a manufacturer of dehydrated onion and garlic, the acquiring firm may be able to use its market power to force other firms to buy the acquired firm's products. "Reciprocal trading may ensue not from bludgeoning or coercion but from more subtle arrangements. A threatened withdrawal of orders if products of an affiliate cease being bought (is one example) ... Reciprocity in trading as a result of an acquisition violates $\$ 7$, if the probability of a lessening of competition is shown" [74]. 


\section{SECTION 3.0}

\section{ENERGY MARKETS}

As we have seen, determination of the relevant market in which to assess the defendant's (and its competitors') power or potential contribution to concentration is critical to antitrust analysis of monopolizations and mergers [75]. And, although other antitrust offenses may be analyzed without an expressly defined market, effected areas of trade or commerce are inevitably isolated for judicial inquiry in antitrust litigation. The market for a given product is considered to include other commodities that consumers would likely view as possible substitutes for the same use(s) for which the product is appropriate [76]. If similar skills and equipment are used in the production of two products with different end uses, such products may be treated as part of the same market, despite the different product uses. This is because of the relative ease with which a producer of one such product could market the other [77]. Geographic definition of a market as local, regional, or national may hinge on the feasibility of transporting the commodity from the production site [781. Similarly, the relevance of import competition may depend on tariff policies that encourage or discourage such competition [79]. The market definitions in this study will be based on national demands unless geographic considerations warrant specific attention.

\subsection{COMPETTTON AMONG ENERGY SOURCES}

SHAC systems will compete with existing energy sources in markets whose end uses require energy in the form of hot or cold air or hot water. The two major markets for these energy forms are: (1) buildings' hot water and space heating and cooling, and (2) industrial and agricultural "process heat" (used to dry grains and crops and in similar applications). These markets' end-use energy requirements are presently satisfied either through the direct consumption of fuels or through the conversion of fuels to produce electricity. Both processes require primary resources-oil, natural gas (gas), coal and uranium-to be refined, transported, and converted to more usable forms before they can perform useful work.

The bulk of the residential and commercial heating and cooling market is shared by oil and gas, with gas dominating. There is competition between oil, gas, and coal to produce agricultural and industrial process heat. All four primary fuel resources serve identical functions in an electric utility power plant.

In addition to intrafuel and interfuel competition, there is also competition between the fuels and electricity. Electrically heated buildings have enjoyed growing popularity since the l950s, partially as a hedge against natural gas and oil price increases. Electric heating benefits the buildings market sector by introducing added competition into a market previously supplied by the fuel companies. But the growth of electric heating may also threaten competition as the electric utilities capture the consumer in toto by promoting the "all-electric home." Counterefforts by the gas industry to maintain its market share by introducing central air conditioning fueled by gas, may not effectively block the increase in totally electric homes.

In the agricultural and industrial market, because most processes require relatively low temperature hot water and steam that are uneconomical when produced electrically, competition between electricity and primary fuels is negligible. Therefore, the market share captured by electricity is confined largely to relatively few industrial users of high 
temperature hot water and steam (e.g., aluminum and steel blast furnaces), who prefer electric heat to the direct combustion of primary fuels. A small pocket of competition may also exist in remote farm areas, where the high price of oil and gas and the impracticality of small-scale coal uses, make electricity a more attractive energy source.

\subsection{ENERGY MARKET STRUCTURE}

The substitutability among energy sources noted in the previous section tends to promote strong competition in energy markets but has been substantially offset by two anticompetitive trends in the energy industry: first, the expansion of many oil companies across the entire energy spectrum, and second, the increasing number of pooling arrangements [8U] among electric utilities. To a lesser extent the diversiflcation of electric utllities into gas distribution also inhibits competition.

The Interfuel Competition Bill [81] was introduced in 1975, seeking horizontal divestiture of the large petroleum companies. Since then, many similar bills have been proposed, each of which essentially seeks to discourage involvement by the petroleum majors in energy sources other than oil and gas. [82]. Proponents of horizontal divestiture point to the opportunity for market manipulation and other anticompetitive practices that may result when a large entity owns its competition [83]. For example, energy companies may unreasonably defer the commercialization of alternate energy sources such as solar and geothermal, in order to protect their existing fossil fuel investments. Furthermore, energy company involvement in emerging industries such as solar energy may, erect barriers to entry by new firms. This would be the first step towards industry concentration. Underlying these concerns is the belief that concentration in the petroleum industry approaches oligopoly levels, and that the probability of tacit collusion is great [84].

Those who oppose horizontal divestiture view the entry of petroleum companies into nonoil energy industries as consistent with the national energy policy to accelerate the development of renewable fuel sources. In the words of one industry defender:

[The expansion by the petroleum majors into nonoil energy] reflects the national reallocative forces of the marketplace in three distinct ways:

- the limits on oil reserves at home and the nationalization of those in which they held an equity position abroad have given oil companies a strong incentive to turn to other energy soureca 'they already have a large investment in managerial expertise and capital involved in the production and marketing of energys

- much of the technology of oil exploration, recovery, and refining is economically transferable to nonoil energy sources; and

- oil companies, by any standard, are large and experienced in making extensive long-term investments that have prospective long-term payoffs. [85]

The fuel companies also point to the lack of factual evidence to support the claims of oligopoly in the petroleum industry. Economists, antitrust scholars, and public policy makers largely agree that "a four-firm concentration ratio of $50 \%$ [86] or less is a cutoff point below which it cannot reasonably be inferred that market power is significant, or that tacit collusion among firms is a likelihood" [87]. In certain circumstances, 
concentration in the $50 \%$ to $70 \%$ range could lead to conscious parallelism, but the real cause for concern arises at levels of $70 \%$ and above [88].

Divestiture opponents point to the fact that the 20 largest fuel companies account for only $47.8 \%$ of fuel production, as an argument against any inference of collusion in the industry [89]. The levels of concentration in each of the traditional energy submarkets excepting uranium (i.e., petroleum, natural gas, and coal) also fall considerably below suspect levels [90]. Still, in an individual case, or with respect to a particular submarket, higher concentration levels or other indicia of anticompetitive performance may justify antitrust intervention. Additionally, as a matter of public policy, prophylactic measures controlling entry-for example-may be imposed on an emerging industry to enhance competitive conditions.

With regard to the electric utilities industry, the degree to which competition exists is artificially controlled primarily by utility regulation, and secondarily by market forces and the antitrust laws. Each regulated utility enjoys a monopoly position within its respective service area. Prevailing public policy has dictated that wasteful duplication of precious resources is too high a cost to pay for competition in the delivery of electricity. Therefore, only small pockets of competition exist in the retail electric market, the most noteworthy of which is competition among utilities to attract large industrial users of electricity to its competing service area. State and federal regulation of electric utilities was once viewed as obviating the need for, and thus supplanting enforcement of the antitrust laws against these utilities. However, landmark cases in the past decade have dispelled this view, holding regulated utilities subject to liability for anticompetitive practices under the antitrust laws [91].

During this same era, legislative amendments to the Atomic Energy Act of 1954 grafted a mandatory antitrust review stage onto the licensing process for applicant nuclear generating facilities [92]. The legislative history of the 1970 amendment indicates that its proponents were concerned by the smaller utilities' inability to reap the benefits of low-cost nuclear power because of the capital investment required; to the extent that utilities "pooled" their capacities, smaller entities potentially had access to the low-cost power, but in fact their participation in any such sharing arrangements had historically been insignificant [93]. The amendments require the Nuclear Regulatory Commission (NRC) to consider, whether the granting of a license for a proposed nuclear facility would "create or maintain a situation inconsistent with the antitrust laws" [94]. If a nuclear facility applicant is or plans to be a party to a power-pooling arrangement, the NRC may condition its license grant on the applicant's providing access of the pool to. smaller utilities.

Viewed in traditional antitrust terms, power pooling among utilities may be classified as joint ventures which violate Clayton $\$ 7$ where they have a "tendency to lessen competition" [95]. Under a rule of reason analysis, a combination will be illegal unless the competitive benefits of the combination outweigh the detriments. Given the trend towards power pooling, and the inability of smaller utilities to achieve economies of scale or to sufficiently invest in new generating facilities, the potential competitive advantages from large-scale solar technologies will likely be limited almost exclusively to large utilities. This threatens not only to dampen interutility retail competition but also to force consumers in the smaller utilities' service areas to pay higher prices relative to consumers served by larger utilities. If large utilities ultimately develop the capabilities to generate low-cost solar electricity, as other fuels become scarce or prohibitively expensive, smaller utilities may become obsolete. Because large-scale, centralized power generation typically promotes economies of scale that allow lower prices, incentives to apply solar technologies to small-scale, decentralized use may be seriously thwarted. 
Even if the pooling of power in solar energy commercialization develops in such a way as to allow survival of smaller utilities, the entry of utilities into the solar industry raises serious questions of horizontal integration. At first glance, the tolerance of integrated gas/electric utilities might suggest that fuel/solar integration would also be tolerated under the antitrust laws. But gas and electric power directly compete only in providing energy for heating and cooling, whereas solar technologies potentially compete with all end uses of electricity. Because solar energy can substitute for electricity in so many end uses, and because regulated entities involvement in unregulated industries is typically suspect [96], entry by utilities into the solar market will probably trigger the application of strict competitive review standards. However, these issues are sufficiently unique and important as to require legislative input. To date, Congress has not acted in this regard; one can only infer possible Congressional responses from existing antitrust and energy legislative policies.

\subsection{IMPACT OF NATIONAL ENERGY POLICIES}

The major provisions in the National Energy Act [97] passed by Congress in 1978 ul'e consistent with the goals stated in President Carter's National Energy Plan. The Plan envisions a three step process, which is implemented in the Act: (1) conservation of energy resources, (2) utility conversion from natural gas and oil to coal, and (3) transition to renewable resources such as solar and geothermal [98]. The third of these strategiestransition to renewable resources-is advanced by research, development, and demonstration (RD\&D) of solar technologies under the auspices of the Department of Energy (DOE). Notwithstanding private efforts to commercialize solar energy, government spending presently dominates the area, and therefore, governmental budgeting priorities among the various technologies and demonstrated market applications will strongly influence their relative strength in the energy markets.

\subsubsection{Buildings}

Federal spending has contributed significantly to the development of solar water and space heating and cooling systems designed for residential or commercial buildings. Approximately $28 \%$ of DOE's $\$ 411$ million solar budget for FY78 was devoted to solar heating and cooling of buildings (SHACOB) and solar hot water (SHW) systems [99]. Hence, it is no coincidence that these systems are the most commercialized applications of solar energy developed to date. Development of heating systems for buildings has also benefitted from the relative ease with which the requisite low-temperature heat can be generated, and the fact that solar collectors are the only technologically new component in solar heating systems. Solar air conditioning systems are also quite advanced, but less economical because the cooling of buildings requires an additional component or process not required in solar heating systems.

\subsubsection{Agricultural and Industrial}

Presently, several types of solar flat-plate and concentrating collectors are available. These collectors are capable of generating the low- and intermediate-temperature air, water, or steam needed for many farming and industrial operations. Systems for agricultural and industrial process heat (AIPH) differ from heating systems for buildings, basically in the higher temperature heat produced by many AIPH systems. AIPH technology development has therefore benefited from the attention and funding devoted to the buildings sector. Additionally, although only $3 \%$ of the FY79 solar budget was 
earmarked for AIPH, concentrating collectors capable of generating medium- and hightemperature heat received $R \& D$ dollars under a different program heading, amounting to a total of approximately $12 \%$ of the total DOE FY78 solar budget [100]. 


\section{SEP拳}




\section{SECTION 4.0}

\section{SOLAR HEATING AND COOLING: AN ANTITRUST ANALYSIS}

The solar technologies developed for low- and medium-temperature heat generation and air cooling are so closely related from a production standpoint, notwithstanding their differing end uses (e.g., domestic space heating and cooling, commercial water heating, or agricultural crop drying), that the relevant market for antitrust analysis of these technologies is the solar heating and cooling industry as a whole. Where SHAC systems' end uses have competitive implications that are significantly different, distinctions will be drawn.

SHAC systems encroach on a market dominated by fuel energy companies and utilities (gas and electric). In repsonse, many of these firms have entered or are contemplating entering the SHAC industry [101]. Whether their involvement benefits or inhibits the growth of a competitive industry is a central issue raised by the antitrust laws [102].

To date, the largest consumer of equipment and services associated with SHAC is the Federal Government. Federal spending policies will, therefore, have a substantial impact on the structure of the future SHAC industry. Choices made now between competing contract proposals benefit the chosen contractor not only directly, via the economic support of the contract itself, but also by influencing state and local officials in administering their solar programs and funds.

Small businesses have a unique opportunity to enter the energy industry because SHAC systems are not highly capital intensive, especially in comparison to traditional energy sources. Indeed, many consumer advocates and environmentalists view the development of solar energy as a means of usurping overgrown corporate power and reducing dependence on centralized institutions [103]. These goals are consistent with the objectives that underlie antitrust enforcement. However, it is debatable whether a SHAC industry composed solely of small enterprises is feasible or desirable in the context of our existing economic structure. If entry into the SHAC industry were restricted to small businesses, it is doubtful their products could compete with substitutes that are cheaper, better known, and typically more respected. Compromise solutions-aimed at coexistence of small and large firms in the SHAC industry-may well be the most appropriate application of antitrust law and national energy policies in this area.

\subsection{COMPETTTIVE PROFILE OF SHAC INDUSTRY}

The structure of the SHAC industry is characterized by organizational diversity. In 1977, solar heating and cooling systems or subsystems were reportedly researched, produced, or serviced by over 300 firms, exclusive of the many backyard enterprisers installing selfstyled solar units. Of these 300 firms, at least 40 (14\%) were listed among the Fortune 500 largest U.S. industrial corporations, an additional 30 firms (10\%) were publicly owned companies, and the balance were privately held companies [104]. Barriers to entering the solar heating and cooling industry are relatively low. The technology is simple and well known. Although many firms have acquired patents in the solar heating and cooling field, the patents on the basic technology have expired, and those patents that are still effective cover design elements that are easily circumvented [105]. Further, initial capital requirements for entry are relatively small. None of the SHAC systems require a scarce or prohibitively expensive resource. In fact, as indicated earlier, solar heating and cooling systems are actually a novel composition of more or less standard building materials such as pipes, sereening, glass, insulation, and pumps. 
The industry is young enough that customer loyalties have not been established. A new market entrant ostensibly has the opportunity to compete on an equal basis with existing firms, although there are countervailing factors. Newcomers to the industry may have to compete with many large firms established in other markets [106], which can carry their goodwill and reputation into solar heating and cooling. Additionally, large and small firms that have received government contract awards are acquiring early market experience and exposure that may be difficult to duplicate later on.

Uncertainties regarding the status and content of product regulations is a barrier not only to new entrants but also to the profitability of existing firms. For example, divergent performance and quality standards burden newcomers, who must tailor their equipment to conform with regulations. Existing products may need expensive adjustments to pass regulatory muster.

At this early stage, market shares based on sales per firm are difficult to compute and of questionable reliability, primarily because low-entry barriers can allow radical changes in the industry's structure. However, larger firms that are presently in other energy markets have significant advantages over existing or potential SHAC competitors. 'I'heir leverage arises partly from their ability to offset solar losses against profits from their other activities. The marketing experience and reputation gained by a diversified firm from work with other products is of ten transferable; smaller solar companies would have to spend exorbitant funds on advertising campaigns to develop comparable public recognition.

\subsection{COMPETTTIVE IMPACT OF FEDERAL SPENDING}

Much activity in the SHAC industry is supported by federal dollars, not only through DOE, but also through the Department of Housing and Urban Development (HUD) and various other federal agencies [107]. To foster competition in the emerging industry, the Solar Heating and Cooling Demonstration Act (SHACDA) requires that these federal officers and agencies take all possible steps to assure that "small-business concerns" will have realistic and adequate opportunities to participate in that program [108]. Participation in SHAC demonstrations will be open to all firms in the industry. A "small-business concern" is statutorily defined [109] as one that is independently owned and operated, and is not dominant in its field of operation. Therefore, a number of companies that are small by current standards and whose presence in the SHAC industry would foster competition, may not be given special consideration under the SHACDA mandate because they have financed their operations by public issuance of stock. A perusal of the RD\&D SHAC work done under government contracts indicates a wide variety of recipients, ranging from Fortune energy and nonenergy companies to small firms developing a single line of solar systems [110]. Ostensibly, federal offices have fulfilled their statutory duty towards small business concerns. However, comprehensive antitrust review should occur at the earliest possible stage if growth of a competitive SHAC industry is to remain possible.

Precontract-award review, according to standards developed through the joint efforts of DOE, FTC, and DOJ, would benefit competition and competitors. Common sense teaches that preventive measures are easier to administer and usually more successful than curative treatments. Furthermore, business organizations should be able to invest in solar technologies with the knowledge that the eventual outcome of their efforts will be determined by free market forces and not by an unexpected antitrust litigation. On the other hand, the paperwork and other bureaucratic necessities associated with federal 
contracting are already time-consuming without the additional burden of an antitrust review process. As an alternative to scrutinizing individual applications, a policy statement might be issued to each prospective contractor, outlining the types of situations DOJ and FTC consider anticompetitive. The statement would be neither conclusive nor exhaustive, but would serve as notice to all applicants. The policy announcement would also provide the flexibility necessary to expedite government contract work, and at the same time develop meaningful standards for future antitrust review.

The legislative mandate in SHACDA does not require any competitive review of contract award. Federal regulatory agencies such as the Interstate Commerce Commission (ICC) or the Federal Maritime Commission (FMC) normally hold such competitive review hearings as a matter of course because they are required to accommodate antitrust policies in carrying out their regulatory duties [111]. By contrast, the functions of agencies involved in overseeing solar $R D \& D$ do not include the economic regulation of a particular industry. Thus, these agencies are neither equipped nor empowered to adjudicate antitrust issues.

If a particular solar contract award appears to violate the antitrust laws, the involved administrative agency would not be vulnerable to litigation so long as it lacks comprehensive regulatory jurisdiction over the contractor [112]. Under such circumstances, the contractor would be the appropriate party defendant. However, under the "NoerrPennington doctrine," an antitrust plaintiff's chances of success are low if the cause of action is based solely on the government contract award [113]. Although recent Supreme Court opinions are closing up many of the antitrust loopholes [114], successful solicitation of federal government action such as a contract award, absent some element of dishonesty or bad faith, remains somewhat impervious to antitrust litigation. As a general rule:

where a restraint upon trade or monopolization is the result of a valid [federal] governmental action, as opposed to private action, no violation of the [Sherman] Act can be made out .... [because a] construction of the Sherman Act that would disqualify people from taking a public position on matters in which they are financially interested would ... deprive the people of their right to petition in the very instances in which that right may be of the most importance to them. [115]

This rule is inapplicable when activity "ostensibly directed toward influencing governmental action is a mere sham to cover what is actually nothing more than an attempt to interfere directly with the business relationships of a competitor..." [116]. For example, if a large manufacturer of flat-plate collectors persuaded HUD to include certain specifications in its bid invitations that would be met by the proponent's products but not by rival products, a violation of the Sherman Act would be likely [117].

Statutory solutions requiring consultation with an antitrust advisory board or agency have been proposed whenever federal action might impact competition in a given market [118]. The procedure envisioned would be roughly analagous to the requirement of an environmental impact statement under the Environmental Protection Act before certain proposed federal actions may be implemented [119]. To date, none of these proposals have received the requisite congressional support, and federal solar contracts, therefore, may be awarded without express consideration of competitive impacts. An individual or company commercially injured as a result of the award has standing to contest the agency's decision on antitrust grounds, but would be ill-advised to litigate the matter unless and until the basis of the claim extends well beyond the contract award itself. 


\subsection{COMPETITIVE IMPACT OF ENERGY COMPANY INVOLVEMENT IN SHAC INDUSTRY}

If federal contract awarding were limited by stringent competitive standards, energy companies would nevertheless be free to invest their own funds in the solar market, absent an overall legislative prohibition against interenergy diversification. The requisite support for such prohibitory legislation is lacking. Under present circumstances, therefore, the only significant limitation on energy company involvement in renewable forms of energy is antitrust law enforcement.

It is well-documented that the energy companies wish to invest in solar energy enterprise. A congressional subcommittee survey of research outlays by the major oil companies found $\$ 3,370,000$ of cumulated expenditures on solar .R\&D in 1978 [120]. Furthermore, at least three of the petroleum majors and one nuclear company have entered the SHAC market, either through internal expansion or external expansion. How Section 2 of the Sherman Act (prohibiting monopolization) and Section 7 of the Clayton Act (prohibiting mergers that tend to lessen competition) may be enforced against energy companies to ensure an organizationally diverse SHAC industry, is the focus of the next section [121].

\subsubsection{Monopolization Under the Sherman Act}

Notwithstanding case law preference for growth by internal (i.e., creating a new department or division) expansion [122], because it adds rather than eliminates a competitor [123], such growth remains subject to antitrust scrutiny. Under Section 2 of the Sherman Act, a single firm is guilty of monopolization if (1) it possesses monopoly power in the relevant market, and (2) that power has been willfully acquired or maintained, rather than naturally developed as a result of superior product, business acumen, or historic accident [124].

Application of these standards to the creation of a SHAC division by an energy company begins with a determination of the relevant market.

Market definition is critical to the outcome of antitrust litigation. In a narrowly defined market, one company's market power is much more evident than in a broadly defined market. In United States v. DuPont [125], the record showed that the defendant produced almost $75 \%$ of the cellophane sold in the United States, and that cellophane constituted less than $20 \%$ of all flexible packaging material sales. Cellophane's interchangeability with other materials (greaseproof paper, glassine, waxed paper, foil, and Pliofilm) sufficed, in the court's opinion, to include all such flexible packaging materials in the relevant product market. In the context of such a broadly defined market, the extent of DuYont's market control did not constitute monopolization [126]. By contrast, in United States v. Grinnell Corporation [127], the court excluded substitutes such as alarm bells or guards as distinct from the market for defendant's central station protective services because of differences in utility, efficiency, and continuity. As the court noted, "for many customers, only central station protection will do" [128]. This narrow characterization of the market dictated a finding of monopolization.

These two cases represent extremes between which the courts fluctuate in determining the relevant market. Despite their differing results, both opinions rely upon the crosselasticity [129] of demand among interchangeable products (or services) to identify the market. In DuPont, from evidence that the defendant's percentage of total wrap sales 
increased while others' decreased during the period when DuPont had been reducing cellophane prices, the court inferred that a high positive cross-elasticity of demand existed between cellophane and other wraps. In Grinell, evidence that insurance underwriters allow a reduction of premiums to customers having approved protective signaling systems, and that consumers were shifting away from "the less integrated, advanced, expensive, and safe method of proprietary systems to accredited [central station protective services indicated al ... major product difference for transcending the obvious possible minimal cross-elasticity of demand" [130].

The extent to which sellers of oil and gas for heating purposes have lost business to SHAC systems has not been quantified. However, consumer conservatism toward untried products and the spectre of regulatory constraints, such as zoning ordinances forbidding the installation of rooftop collectors, sets SHAC systems apart from fossil fuels and suggests that there would likely be negative cross-elasticity between these energy forms. Yet the end-use interchangeability between these solar systems and oil and gas suggests that they will compete in the same markets. Evidence or speculation suggesting negative cross-elasticity can be attributed largely to the newness of solar technologies. Time will probably erode existing consumer hesitancies, promoting positive cross-elasticity at some future date.

From a production standpoint, SHAC systems are distinctly separate from oil and gas. Oil and gas. are natural resources whose discovery, development, production, and marketing is capital intensive, and subject to government regulations [131]. Production of SHAC systems requires modest start-up capital, and the systems presently are regulated only by performance and quality standards designed largely to protect the consumer/buyer. Thus, although end-use criteria suggest a horizontal relationship between oil and gas and SHAC systems, overriding production differences should be factored into any market analysis. Where a showing of anticompetitive purpose or effect is made, courts often tend to narrowly define the defendant's relevant market. Thus, even though SHAC systems compete with oil and gas in markets for the heating and cooling of buildings, if one of the larger energy companies with a SHAC division were sued by a small company whose sole production is in SHAC systems, arguments based on production, marketing, and consumer preference distinctions might persuade the court that SHAC systems constitute a distinct product market.

Because SHAC relies on the sun as its "fuel," varying climatic conditions across the United States suggest that geographic factors will receive considerable attention in defining the relevant market in Shermon \$2 litigation. The geographic market is "the area in which the seller operates [and in which it is] willing to compete for consumer potential" [132]. Consumption patterns provide evidence of the effective area of competition.

Although a producer of SHAC systems may operate its business on a national level, commercial realities in the SHAC industry recognize well-defined submarkets because the requisite amount of insolation exists only in certain areas. Also, system installation and maintenance, requiring local relationships, is typically essential to the operation of the solar system or product [133]. A third factor favoring recognition of geographical submarkets is the price and availability of natural gas. Economic feasibility studies indicate that SHAC systems will be less popular in regions where natural gas is a cheaper alternative [134]. Given that a seller's marketing decisions are influenced by its knowledge that certain geographic regions are not well suited to SHAC systems, only areas targeted as profitable would be actively solicited and serviced, and outlying regions would be excluded from the relevant geographic market. 
Sherman $\$ 2$ analysis calls for an assessment of the defendant's market power within each relevant product and geographic market. Actual control over prices or the actual exclusion of competitors creates a presumption of monopoly power [135]. Absent such clear evidence of dominance, an extensive evaluation of the market structure and functioning is of ten necessary to determine whether the defendant's power over supply, price, or entry is monopolistic. Where the defendant's share of the market rises to a suspect level, the market analysis may be less extensive because size-although insufficient to constitute a Sherman $\$ 2$ violation in and of itself-is a significant "earmark of monopoly power" [136].

As indicated in DuPont [137], market share is measured by the firm's output or sales in the relevant market and is expressed as a percentage of-the total output or sales of all competitors in the market. Ninety percent has been stated as "enough to conslilule $a$ monopoly; [whereas] it is doubtful whether $60 \%$ or $64 \%$ would be enough; and certainly $33 \%$ is not" [138]. Although the "relative effect of a percentage command of a market varies with the setting in which that factor is placed" [139], the Supreme Court has followed the aforementioned percentage guidelines with some consistency [140], and two circuit court decisions [141] have noted that monopolization has never been found when the market share of the defendant is below 70\%. In U.S. v. Grinnell [142], the Supreme Court noted in dicta that "the existence of [monopoly] power ordinarily may be inferred from the predominant share of the market ... $87 \%$ of the [relevant market] leaves no doubt that ... these defendants have monopoly power ..." [143].

As suggested earlier [144], current market shares may be unreliable for market analysis of the emerging SHAC industry. Yet a sufficiently large, early market position acquired by a large firm may be somewhat immune to competition from later entrants. Thus, if an energy company's total sales currently constitute a very high percentage of sales ill the relevant market, the probability of future entry should not destroy the probative value of the early market share. Although presently available statistics do not indicate that any energy company has acquired such a suspect share of the SHAC market output [145], changing conditions may soon produce new sales figures.

In spite of a lack of accusatory market share data, there are alternative bases for showing monopoly power, such as predatory acts to suppress competition or control over an indispensable industry resource or service. Where willful control or maintenance of a significant part of the market is shown, the court may infer monopoly power from the defendant's ability to effectuate its anticompetitive purpose [146]. For example, an energy company that sells SHAC systems below its cost manifests monopoly power through its ability to control pricing and exclude competitors. The illegality of such conduct is based on sound reasoning because consumers' preference for the defendant's product would most likely be based on the attractive price. The incentive to compete through product improvements is avoided by price competition, and sellers who wish to concentrate on product quality or performance may be forced to cut corners or absorb financial losses to meet the defendant's prices.

A situation might also arise where a manufacturer of SHAC systems requires purchasers to use only that manufacturer's brand of liquid as the heat transfer medium for the system. Such an arrangement is vulnerable to attack as an illegal tie-in under Section 3 of the Clayton Act, and is also evidence of deliberate acquisition or maintenance of monopoly power where the relevant market is heat transfer mediums for SHAC systems. One possible defense under either Clayton $\$ 3$ or Sherman $\$ 2$ is safety or product performance; i.e., that the manufacturer's brand is uniquely suited to its system, and use of other brands would be dangerous or inefficient [147]. However, where less 
restrictive alternatives are available, such as providing specifications for the type of heat transfer fluid required, the defense is not likely to succeed. Given the present state of the art, it is unlikely that any manufacturer could support a claim of SHAC system fluid uniqueness.

A significant technological deficiency in SHAC is the lack of economical and practical thermal storage systems. Given the fluctuations in solar radiation, the need for back-up heating and cooling systems will be obviated only when the deficiency is overcome. Research to date suggests that the most effective storage system ultimately marketed will utilize a unique process or resource. If such a system is privately designed and patented, the competitive profile of the SHAC industry will undergo severe changes, because of the competitive advantages of marketing an integrated SHAC storage system. Although the manufacturer's patented process is protected from direct antitrust attack, use of the patented storage system to increase sales of the heating and cooling system is not protected. If the manufacturer requires a customer to purchase an integrated system where the integral parts are functionally severable, the manufacturer may be required to sever the parts or alternatively make the storage unit available to competitors [1 48].

\subsubsection{External Growth Under the Clayton Act}

Growth through external expansion (e.g., merger, acquisition, or joint venture) is vulnerable to $\$ 7$ of the Clayton Act. The $\$ 7$ language prohibiting expansions that "tend to lessen competition or create a monopoly," was intended to catch monopolies in their incipiency.

In 1976, Clayton $\$ 7 \mathrm{~A}$ was enacted [149], requiring advance notice to the government of large mergers. Notice must be given where (1) the acquiring company has total assets or sales of at least $\$ 100$ million, and (2) the acquired company has assets or annual net sales of $\$ 10$ million. A transaction is subject to the premerger notification requirement if the acquiring company holds more than $\$ 15$ million worth, or at least $15 \%$ of the voting securities or assets of the acquired company. Acquisitions by any of the large energy companies [150] would come under the Act if the acquired company met the $\$ 10$ million threshold stated above. Sales in the SHAC industry totaled about $\$ 150$ million in 1977 , and four firms reported sales of over $\$ 10$ million for that year. [151]

Mergers are classified as horizontal, vertical, or conglomerate, and each category is judged by different standards. A marriage between an energy company and a SHAC system manufacturer may be viewed as either a horizontal or a conglomerate merger. If the merging entities were competitors before the merger, it is horizontal; otherwise, it is conglomerate. Although all mergers are within the reach of $\$ 7$ [152], each category does carry with it separate case law precedent and DOJ merger guidelines. In any merger case, the application of $\$ 7$ requires a determination of the affected line(s) of commerce. There is a difference between line of commerce demarcation and merger classification. Determining that the merger was horizontal because of business competition between the energy company and the acquired SHAC manufacturer for the heating and cooling of buildings, does not preclude a much narrower finding regarding line of commerce; i.e., SHAC systems.

Regardless of the merger label, the probable "line of commerce" isolated in an energy company/SHAC system manufacturer marriage would be SHAC systems. In Brown Shoe Co. v. U.S. [153], the court recognized that there may be broad markets, whose "outer 
boundaries ... are determined by the reasonable interchangeability of use or the crosselasticity of demand between the product itself and substitutes for it ...., [yet] welldefined submarkets" may constitute the appropriate line of commerce [154]. A perusal of the merger case law indicates that the courts have accepted relatively narrow product lines as separate submarkets [155], because market boundaries are drawn to reflect "[c]ompetition where, in fact, it exists ..." [156]. Such a submarket determination is consistent with criteria set forth in the Brown Shoe opinion: "industry or public recognition of the submarket as a separate economic entity, the product's peculiar characteristics and uses, unique production facilities, distinct customers, distinct prices, sensitivity to price changes and specialized vendors ..." [157].

In Brown Shoe, the court stated that the geographic market must "both 'correspond to the commerical realities' of the industry and be economically significant" [158]. A noteworthy distinction between Sherman $\$ 2$ and Clayton $\$ 7$ is that Clayton $\$ 7$ requires some interstate nexus, whereas Sherman $\$ 2$ may be invoked even where the affected area has a small population and is economically insignificant in the country as a whole [159].

Once the relevant market is defined, the distinctions between horizontal and conglomerate mergers become relevant. In a horizontal situation, concern is focused on the elimination of a competitor and the concomitant. increase in market concentration. Conglomerate mergers, by contrast, replace a prior competitor with a new, larger entity. Rather than examining market concentration, the courts scrutinize the market to determine whether the merger raises entry barriers, eliminates competition, or creates opportunities for reciprocity. The end-use interchangeability between oil and gas and SHAC system provides a strong, if not conclusive, basis for characterizing mergers between sellers from these two industries as horizontal. In the situation wherein an oil and gas company merges with a SHAC system manufacturer whose geographic service area is different, the merger would be conglomerate.

DOJ merger guidelines with respect to horizontal mergers state the Department's enforcement activity under Clayton $\$ 7$ to have the following interrelated purposes:

(i) preventing elimination as an independent business entity of any company likely to have been a substantial competitive influence in a market;

(ii) preventing any company or small group of companies from obtaining a position of dominance in a market;

(iii) preventing significant increases in concentration in a market; and

(iv) preserving significant possibilities for eventual deconcentration in a concentrated market. [160]

In a highly concentrated market, which is defined as one in which the shares of the four largest firms amount to about $75 \%$ or more, mergers between firms with relatively small market shares (e.g., 4\% plus $4 \%$ ) will "ordinarily" be challenged by the Department; in a less highly concentrated market (i.e., the four largest firms account for less than $75 \%$ of the market), the Department's policy is more lenient. In either case, the standard is stricter if there is a significant trend towards concentration in the relevant market [161]. The horizontal merger case law stresses the same empirical factors-market shares, concentration ratios, and industry concentration levels. In United States v. Philadelphia National Bank [162], the Court stated a basic standard of illegality: 
[A] merger which produces a firm controlling an undue percentage share of the relevant market, and results in a significant increase in the concentration of firms in that market, is so inherently likely to lessen competition substantially that it must be enjoined in the absence of evidence clearly showing that the merger is not likely to have such anticompetitive effects. [163]

The merger in question was held presumptively unlawful because the merged bank enjoyed more than a $30 \%$ market share and increased concentration by more than $33 \%$ [164]. Subsequent cases, following the Philadelphia National Bank test, have found Clayton $\$ 7$ illegality based on much smaller market shares where there is an industry trend toward concentration [165].

Notwithstanding the organizational diversity that presently characterizes the SHAC industry, "the chief executives of the solar companies are almost unanimous in proclaiming [mergers] to be the wave of the future" [166]. One can anticipate a certain degree of tolerance for such potentially illegal Clayton $\$ 7$ activity. However, once the merger activity becomes identifiable as a trend, any horizontal merger is likely to be enjoined under Philadelphia National Bank. The underlying fear is:

that a market marked at the same time by both a continuous decline in the number of small businesses and a large number of mergers would slowly but eventually gravitate from a market of many small competitors to one dominated by one or a few grants, and competition would thereby be destroyed. [167]

Because several SHAC companies have already gone out of business and others face serious problems [168], invocation of the "failing company doctrine" could legalize an otherwise violative Clayton $\$ 7$ merger. In Citizen Publishing Company v. U.S. [169], the Supreme Court held that this doctrine would justify a merger only if "the prospects of reorganization of the [acquired] firm [werel dim or nonexistent ... [and] the company that acquires the failing company or brings it under dominion is the only available purchaser ..." [170]. If another person or group, other than a significant competitor, could be interested in acquiring the failing firm, so that "a unit in the competitive system would be preserved" [171], the doctrine would not be applicable. Furthermore, the court placed the "burden of proving that the conditions of the failing company doctrine have been satisfied ... on those who seek refuge under it" [172]. Thus, the challenged acquiring company must show that no form of reorganization, even under the bankruptcy laws, was feasible [173]. Although the failing company doctrine has been accepted in a few instances [174], the majority of cases passing on the issue have held the defense inapplicable because the defendant has failed to prove the specific elements required by Citizen Publishing [175].

A conglomerate merger of the "market extension" variation would be the appropriate label for a merger between, for example, a natural gas producer in Texas and a SHAC system manufacturer in Colorado. Such mergers may eliminate either the acquiring or the acquired company as a potential competitor, depending on the premerger identity of the entities, the structure and competitiveness of the market, the likelihood that the eliminated company would have entered the market de novo (i.e., independently), and the number of other potential entrants [176]. In the previous example, the relevant market would be SHAC system manufacturing in Colorado. The essential inquiry under Clayton $\$ 7$ is the merger's competitive effects on that market. Under present market conditions the substitution may actually be procompetitive if the conglomerate merger substitutes a 
firm with-diversified business interests for a smaller single enterprise. Efficiencies of operation may bring prices down. Furthermore, total sales in the relevant market may increase if the large company's presence in the market instills consumer confidence in SHAC. On the other hand, given the trend towards mergers is perceived as inevitable, the SHAC industry will reach a point at which entry by the conglomerate would be anticompetitive. If a large natural gas producer acquires a SHAC manufacturer that already enjoys a dominant position in the relevant SHAC market, the acquisition is vulnerable under Clayton $\$ 7$ on the grounds that it will intensify the trend towards concentration and entrench the preexisting dominance.

Two closely related standards for judging competitive consequences of a conglomerate merger in a concentrated market have been approved by some circuit courts. The "actual potential entrant" theory holds that, if the large acquiring firm "at some future date is expected to enter the market de novo or through a 'toehold' acquisition of a firm lacking a significant share of the market" [177], then the acquiring firm's premerger presence on the periphery of the market exerts a procompetitive effect on that market, and the merger by which such potential entrant combines with a significant competitor would violate Clayton $\$ 7$. The underlying rationale is that

the existencé of an aggressivè, weil-equipped, and well-financed corporation engaged in the same or related lines of commerce waiting anxiously to enter an oligopolistic market would be a substantial incentive to competition which cannot be underestimated. [178]

The "perceived" or "recognized" potential entrant theory is based on the same rationale but focuses on the premerger effect that the acquiring company had on competitors in the market regardless of such acquiring company's actual intentions. If the "insiders view the outsider as a likely entrant (a competitor waiting in the wings), they keep prices and profit margins lower than they would if there were no threat of the outsider entering the market ..." [179]. Thus, in United States v. Phillips Petroleum Co. [180], although the alleged potential entrant provided evidence that it planned no entry, the court found objective evidence of resources, opportunity, and motivation to enter a market de novo to be sufficient to establish that the firm was a significant potential entrant.

Whether the loss of "actual" or "perceived" potential competition is sufficient to sustain a Clayton $\$ 7$ violation depends on the competitive structure of the market. If the shares of the eight largest firms in the market amount to $75 \%$, a merger between a potential entrant and a rapidly growing firm, or a firm whose market share is not insubstantial will ordinarily be challenged by DOJ. Absent such a showing of concentration, proof that an industry is moving toward concentration has been sufficient to enjoin conglomerate mergers that might further the trend [181]. The case law is consistent with DOJ policy that accords primary significance to the firm's capability of entering on a competitively significant scale relative to the capability of other firms (i.e., the technological and financial resources available to it), and to the firm's economic incentive to enter (evidenced by, for example, the general attractiveness of the market in terms of risk and profit, any special relationship of the firm to the market, the firm's manifested interest in entry, or the natural expansion pattern of the firm) [182]. The DOJ has taken the argument one step further:

The Department has used Section 7.0 to [challenge] mergers which may diminish long-run possibilities of enhanced competition resulting from technological developments that may increase interproduct competition 
between industries whose products are presently relatively imperfect substitutes. [183]

Experience indicates that deconcentrating an industry is of ten impractical. Although Clayton standards, as applied by DOJ, provide a preferable mechanism for preventing oligopoly, case law support for such an approach is lacking. Lower courts have rejected government arguments that conglomerate mergers involving large firms violate Section 7 by merely contributing to the "rising tide of economic concentration in American industry" [184]. Apparently, courts are reluctant to use the Clayton Act so aggressively because:

[w] hatever may be the merits of the arguments as a matter of social and economic policy in favor of, or opposed to, a standard for measuring the legality of a merger under the antitrust laws by the degree to which it may increase economic concentration rather than by the degree to which it may lessen competition, that is beyond the competence of the Court to adjudicate .... [n $\mathrm{f}$ that standard is to be changed, it is fundamental under our system of government that any decision to change the standard be made by the Congress and not by the courts. [185]

Thus, although technological developments in SHAC may stimulate interproduct competition between SHAC and oil and gas, the possibility of enhanced long-run competition may be diminshed by conglomerate mergers that are presently seen by the courts as outside the scope of Clayton $\$ 7$.

An alternative basis for attacking conglomerate mergers exists where the merger increases the probability of reciprocal dealing. Reciprocity refers to "a seller's practice of utilizing the volume or potential volume of its purchase to induce others to purchase its products in preference to those of its competitors" [186]. Assume, for example, an acquisition of a SHAC company by an acquiring company that is also a large purchaser of paper products from a particular paper supplier. If that paper supplier is considering the use of flat-plate solar collectors to produce the heat necesary for paper processing, the new conglomerate entity will be in a position to condition future purchases on the receipt of orders for the new conglomerate's solar collectors.

The Supreme Court has held that such reciprocity made possible through conglomerate mergers "is one of the congeries of anticompetitive practices at which the antitrust laws are aimed [because it introduces] an irrelevant and alien factor . . . into the choice among competing products, creating at the least 'a priority on the business at equal prices"' [187]. Any acquisition which offers an opportunity for reciprocal buying does not necessarily violate Clayton $\$ 7$. "But where ... the acquisition is of a company that commands a substantial share of the market, a finding of probability of reciprocal buying ... [will result] if there is substantial evidence to support it" [188].

\subsection{COMPETITIVE-IMPACT OP UTHITY COMPANY INVOLVEMENT IN SHAC INDUSTRY}

Because the electric utility industry is subject to pervasive regulation at the state and federal levels, each utility's business decisions are somewhat insulated from free market forces. Within the scope of their regulated activities, utilities enjoy a limited immunity from antitrust scrutiny. However, recent Supreme Court decisions make it clear that any immunity will be narrowly construed and that unregulated activities will be subject to full enforcement of the antitrust laws. Utility involvement in SHAC could come in 
any of four capacities: as a seller, a lessor, a servicer, or a financer [189]. Any reluctance to enter the SHAC market is largely a function of utilities' regulated status and the operation of the antitrust laws.

\subsubsection{Interaction Between Regulation and Antitrust Enforcement}

As a general rule, only those commercial activities expressly excluded by Congress from antitrust coverage are immune to antitrust scrutiny [190]. Because exclusion from coverage is the exception, the courts will narrowly construe such congressional expressions of immunity.

The presumption against implied exclusions from antitrust coverage can be overridden in situations to which the Noerr-Pennington doctrine applies. As discussed earlier [191], this doctrine protects from antitrust attack concerted efforts to influence law makers to enact legislation beneficial to themselves or detrimental to competition, so long as such efforts are not "sham." In essence, this approach values the constitutional right to petition the government above the free market that is protected by the antitrust laws.

A second basis for overriding the presumption of antitrust law applicability was identified in Parker v. Brown [192], where the court recognized that a state's authority to regulate commercial "matters of local concern on which Congress has not spoken" [193], overrides the application of the antitrust laws "so long as the state action serves local ends and does not discriminate against [interstate] commerce" [194].

In Parker, state action displacing competition in the marketing of raisins did not violate the Sherman Act. The state's marketing plan for raisins was consistent with a federal statute authorizing marketing restrictions on agricultural products, which persuaded the Court that Congress intended to allow such regulatory activity to displace federal antitrust law. Under Parker and subsequent decisions, the immunized conduct is strictly limited to "official action taken by state officers" [195], and no antitrust immunity is conferred upon conduct that results from a blend of private and public decision making [196]. Even pervasive state legislation of an industry-does not immunize the resulting conduct under the Parker doctrine because "approval by a State Public Utilities Commission does not transmute a practice initiated by the utility and approved by the Commission into state action" [197]. However, regulated activity at the state or federal level may enjoy a limited implied exemption where there is a "plain repugnancy between the antitrust and [other state or federal] regulatory provisions" [198]. Activity subject to such regulation may be shielded from the antitrust laws if (1) there is a "pervasive regulatory scheme including [considerations of] the antitrust laws" [199], and (2) "the exemption is necessary to make the regulatory act work" [200]. Even then, the exemption will be implied "only to the minimum extent necessary" [201].

The Parker doctrine's application is limited to activity that has already been subjected to competitive review by the appropriate regulatory body. Because "sporadic action" by the courts tends to throw a regulatory scheme "out of balance" [202], the courts generally respect Commission decisions that are correct applications of the relevant statute. However, unless the Court determines that the regulatory body's jurisdiction is exclusive [203], such respect requires only "prior resort" [204] to an agency and does not preclude courts from ultimately determining application of the antitrust laws [205]. State public utilities commission (PUC) proceedings fall into the category where prior resort to the PUC is necessary to protect the integrity of that regulatory scheme. The courts may thus stay proceedings in an antitrust case pending the outcome of PUC 
proceedings [206]. However, once the PUC has considered the matter, the court is in a "position to determine whether the antitrust action should go forward" [207].

Except for municipal utilities and rural cooperatives, each electric utility's retail rates and services are regulated by the state PUC. Where the PUC determines that the public interest would be served by granting a utility the right to operate, it will certify the utility for an exclusive service area. The utility's monopolization of the retail market in electricity in the certified area will not violate the Sherman Act so long as the rates and practices are the result of meaningful regulation, and supervision by the PUC is pursuant to a pervasive regulatory scheme that can only work if such regulated monopolies are tolerated [208].

In recent years, utilities have come under antitrust attack for using their monopoly power to gain competitive advantages or to harm competitors in other markets. In as much as the electric utility's service area is tolerated because competition is viewed as being wasteful of resources, the rationale behind such protective regulation no longer applies when a utility expands its operations into other markets. In such cases, the utility will probably be subject to direct application of antitrust principles.

In Cantor Selden v. Detroit Edison [209], the defendant electric utility was supplying its customers with light bulbs free of cost. Cantor, a seller of light bulbs, sued Detroit Edison, alleging that the utility's practice was an attempt to monopolize the retail light bulb market in violation of Section 2 of the Sherman Act [210] and an illegal tie-in under Section 3 of the Clayton Act [211].

Because the cost of providing the light bulbs was included in the utility's rate basis [212], when the Michigan Public Service Commission approved the defendant's tariff, sub silentio, the light bulb distribution program became mandatory under state law. Although state-sanctioned anticompetitive activities that are "comparably imperative" or "crucial" [213] to the operation of an otherwise valid regulatory scheme may remain immune from attack as necessary [214], the "ancillary" activities of a regulated firm are granted no immunity. A majority of the court therefore agreed that the public utility certified to distribute electricity was not justified in entering the ancillary retail light bulb sales market [215], even though the state had sanctioned the activities [216].

Application of the Sherman $\$ 2$ standards to Detroit Edison's light bulb program resulted in an interpretation of an attempt to monopolize. In Cantor, the relevant market was retail sales of standard-sized light bulbs in the Detroit area. Evidence adduced at trial indicated that the utility was supplying almost $50 \%$ of the total demand in the relevant market [217]. The Supreme Court has not directly ruled on the necessity to establish a relevant market and the corresponding market shares in cases alleging attempted monopolization. However, the lower court cases appear somewhat uniform in holding that power in the relevant market falling short of monopoly does not necessarily contradict an unlawful attempt to monopolize, where "specific intent" to monopolize is shown [218] and there is a "dangerous probability" that the attempt will be successful [219]. 
The kind of conduct that typically establishes the requisite intent to monopolize will vary according to the facts of each case, but the decisions are consistent in carefully scrutinizing actions by already dominant entities:

Firms possessing monopoly power may not be ipso facto unlawful monopolies under the antitrust laws, but the permissible limits of lawful business conduct for such firms are more narrowly circumscribed than in the case of firms not possessing such economic power ..... The right of a monopolist to exploit his monopoly ... . by charging a monopolist's discriminatory price does not .... include the right to destroy or cripple a major segment of an industry, but must yield ... to the policy of competition embodied in the antitrust laws. [220]

Thus, in an attempt case, "intent and power are alternatives to each other" [221]. Even "honestly industrial" market practices may violate the Sherman Act if they are not the "inevitable consequences of ability, natural forces, or law ... [and are used to] further the dominance of a particular firm" [222].

Detroit Edison's light bulb distribution was subject to this higher standard of scrutiny because of its regulated monopoly status. No specific intent need be proven in light of the utility's predatory pricing activities (i.e., light bulbs free of charge to its utility customers), which cannot be justified by normal economic considerations. Also, the fact that Detroit succeeded in supplying $50 \%$ of the demand in the standard-sized light bulb market constituted a "dangerous probability" that the attempt would be successful.

The facts in Cantor may be analogous to the situation in which a regulated utility enters the SHAC market. Most state statutes authorize the PUC to regulate the energy supply market, which is typically defined as the supply of electricity or gas. Under such a statute, the SHAC market could be viewed as ancillary to the supply of electricity or gas, and a utility might be inviting antitrust litigation by using its monopoly power to gain a competitive advantage in the SHAC industry.

As suggested earlier, at least four levels of direct utility involvement in the SHAC industry have been predicted: selling, leasing, servicing, or financing SHAC systems. The antitrust review standard applicable to such activity will vary according to the state's degree of involvement. If state legislation requires the utility involvement with SHAC, the Parker doctrine may immunize the activity from antitrust scrutiny. Where the state PUCs enabling legislation include regulatory jurisdiction over the sale of SHAC devices, the antitrust laws would apply, subject to the prior resort doctrine, Absent express state coverage, the utilities unregulated entry into the SHAC market will be subject to full enforcement of the antitrust laws under C.antor.

\subsubsection{Utility Financing SHAC Systems}

A perceived barrier to the utilization of SHAC systems in existing buildings is the capital expenditures required to purchase the equipment and retrofit the building [223]. Given that conversion to renewable forms of energy is a matter of federal policy [224] and that the National Energy Act calls for state cooperation in the conversion and conservation effort, state legislation requiring utilities to finance SHAC system purchases upon request is a plausible way for a state to fulfill its duties. In some states, utilities have begun financing insulation purchases [225], so there is precedent for such utility involvement. 
The financing market is highly regulated, and the utility would be subject to many relevant rules and regulations [226], such as requirements for disclosure of credit terms and nonusurious interest rates. Whether the PUC would have jurisdiction over the utility's financing functions would be a matter of state law. However, even absent such specific jurisdiction, attempts to include the utility's cost of extending credit in its overall rate basis would be generally prohibited under the standard PUC rate oversight function [227].

Where a utility enters into SHAC financing, in the absence of some abuse of its monopoly power or evidence that its entry into the financing market has had an anticompetitive effect, the conduct may be entirely legal. Under Parker [228], the utility behavior will find support where its conduct is required by state law, provided such state law is prima facie consistent with federal policy.

However, both the absence of a pervasive regulatory scheme for utility financing, as well as the ancillary nature of the financing activity to the utility's primary energy supplying function, places the conduct within the Cantor [229] holding.

Clear abuses of a utility's monopoly power in the retail electric market, so as to gain a competitive edge in the complementary SHAC system financing market, will be struck down by the court. Tying arrangements of any sort are per se illegal under the Sherman Act when the defendant is a monopolist [230]. Thus, a utility would violate the statute if it required its electric customers to finance SHAC equipment through the utility, or if the extension of credit was conditioned upon utilizing the utility's back-up services. Similarly, conditioning the granting of credit upon the purchase of a particular manufacturer's system, or upon any affirmative action not reasonably related to the credit agreement, would violate the Sherman Act. A bona fide requirement that the SHAC system meet certain performance standards may be justified [231].

\subsubsection{Utility Servicing and Repairing SHAC Systems}

At present, servicing in the SHAC industry is performed by persons with technical skills in related equipment, such as plumbers, refrigerator and air conditioning repairpersons, or electricians. But state law might also conceivably require utility servicing and repairing of SHAC systems. Antitrust analysis of such a requirement would differ somewhat from the analysis of utility financing of SHAC. In the financing context, the utility, like any participant in the credit market, has affirmative statutory duties regarding credit terms and interest rates. Therefore, although the antitrust laws will apply, the credit regulations provide a first line of defense against unfair conduct. In the skilled labor market, the absence of legislative standards increases the importance of antitrust review.

As indicated in the financing context [232], the public utility cannot use its monopoly power to secure a competitive edge in the market for SHAC labor services. With respect to prices, Sherman $\$ 2$ is violated when a monopolist charges predatory prices to undercut its competitors [233]. Although the PUC's rate review process ostensibly prevents the utility from including costs of its unregulated functions in its regulated electric rate basis, the opportunity for such manipulation remains, and competitors who lost business because of a utility's predatory pricing scheme could seek relief under the Sherman Act. Affected electric customers who paid prices above the cost of service are also potential plaintiffs. 
Absent a state mandate, utility servicing of SHAC systems is unlikely unless the utility actually enters the sales end of the SHAC market. The profitability of providing services alone is low. In contrast, selling or leasing SHAC systems presents an attractive opportunity for the utility given the foreseeable cross elasticity of demand between SHAC and electric heating and cooling.

\subsubsection{Utility Selling or Leasing SHAC Systems}

In view of Supreme Court disapproval for utility anticompetitive activities in unregulated markets [234], and given the horizontal relationship in terms of end uses between electricity and SHAC systems, voluntary utility entry into the SHAC industry as a vendor contradicts antitrust policy. The utility's lawfully acquired monopoly status in the regulated electric market subjects the utility to the highest standards of antitrust review. Conduct that goes beyond the scope of its PUC certificate is almost presumptively unlawful when the conduct enhances or enlarges the monopoly power. Even if the utility's business practices are "honestly industrial" [235], under Sherman $\$ 2$ a dominant entity is denied the right to "exercise [its] control of the market by business policies that are not the inevitable consequences of its capacities" [236]. Even if the state confers authority on the PUC to regulate public utility sales of SHAC systems, illegality is likely because PUC approval does not "transmute a practice initiated by the utility into state action" [237].

The legality of utility entry into the SHAC market is less easily resolved if the state legislature requires the utility to sell SHAC systems as part of its regulatory duty to supply energy services. Assuming the necessary PUC regulatory authority and that otherwise unregulated entities are freely competing in the SHAC market, the court would be faced with a direct conflict between the state scheme and antitrust policy. The Parker decision would not control this issue because-in contrast with the protected state marketing plan in Parker, which was consistent with other federal legislation [238]-there has been no congressional indication that SHAC sales should be subject to economic regulation or that utilities should be allowed to enter the SHAC market. Although the National Energy Act represents a public policy to convert to solar energy, this legislation is too general to support such a potentially anticompetitive state policy.

In Schwegmann Bros. v. Calvert Distillers Corp. [239], decided after Parker, although the Supreme Court recognized that certain economic areas may be regulated by both federal and state law, if Congress neither intended to preempt the field, nor to defer to state law, the Supreme Court held that states have no authority to grant exemptions from federal antitrust law by enacting legislation that "demands private conduct which the Sherman Act forbids" [240]. And in Cantor-Selden [241], a majority of the Court agreed that state-compelled "ancillary" business practices of regulated firms (such as the light bulb program in Cantor) are subject to strict federal antitrust scrutiny [242]; the Parker "state action" theory would be relevant to ease antitrust scrutiny only if extensive state involvement with an activity would render application of antitrust sanctions to particular entities unfair [243]. Ultimately, the question is whether the state-sanctioned activity is "ancillary" or "crucial" to the state regulatory scheme.

Chief Justice Burger's concurring opinion in Cantor-Selden suggests that he would apply the federal antitrust laws when a state regulates a public utility as a natural monopoly and where the state statute, by its terms "also purports, without any independent regulatory purpose, to control the utility's activity in separate, competitive markets ... [because] undifferentiated sanction of ancillary practice[s]," cannot give rise 
to state action immunity [244]. Underlying the Chief Justice's reasoning lurks the notion that the Sherman Act does not displace existing state regulatory schemes [245], so long as they are within the sphere of state sovereignty [246] and do not place a burden on interstate commerce [247]. Thus, in the setting of state-sanctioned utility SHAC activity, this analysis would hold that regulation of SHAC systems is not ancillary to the state scheme because the utility is required to sell the systems as part of its service duties, over which the PUC has express jurisdiction.

By contrast, Justice Blackmun's concurring opinion in Cantor-Selden suggests that the Court should determine whether the state-sponsored anticompetitive activity is supported by substantial justification [248]. Although such an approach forces the Court to make an ad hoc determination of the reasonableness of the state's legislation [249], the alternative suggested by the Chief Justice would allow the state to legislatively immunize a utility's activity in ancillary markets from antitrust scrutiny. Where statesanctioned utility activity cannot be readily classified as either "crucial" or "ancillary" to the state's utility regulation, Justice Blackmun's requirement that the state show some ineffectiveness of competition in the unregulated market appears well-founded. Indeed, the existence of regulated utility monopolies is of ten justified on the grounds that competition would be impossible or wasteful. An electric utility's monopoly status is tolerated because one firm per service area can satisfy the market demand more efficiently than several competitors, and the normal results of a competitive market regarding price and output are maintained through the regulatory process. If such protected entities are to enter an unregulated industry like SHAC, the state ought to proffer some evidence that competition in such industry is ineffective.

For example, if a state implemented unusual SHAC quality and performance standards to protect its citizens, and those standards made the state an unprofitable sales target for SHAC manufacturers, the state reasonably might find it necessary to require regulated utilities to market the products under PUC supervision. Such a scheme is reasonable and consistent with federal energy policy. The fact that the utility's monopoly power in the heating and cooling market becomes further entrenched as a result, may be tolerable given the nonavailability of SHAC systems in the state. Arguably, any peculiar state characteristics that create a disincentive to vendors of SHAC systems may provide a justification for utility involvement coupled with PUC jurisdiction. However, if the overriding federal goal, conversion to solar, can be accomplished through alternatives less restrictive of competition, the Court may require the state to implement the alternative program.

Judicial discretion in treating utility entry into the SHAC industry can be focused on the choice of remedy where an antitrust violation is found [250]. Remembering the fairness language in Cantor [251], the Court's decree ought not to be geared towards punishing or unduly burdening the utility, but rather towards effecting the state's goals in the least anticompetitive manner. If the utility marketing program was initiated because of unusual product standards, an appropriate decree might enjoin the utility from entering the SHAC market as a seller and instead require the utility to make "qualified" systems available to purchasers through leasing arrangements. Such an alternative might allow manufacturers whose products met state standards to eventually enter the market de novo without fear of competing with the utility. A court usually retains jurisdiction to modify the decree [252]. At some future date, such modification may include a requirement that the utility abandon its position in the SHAC market by selling out any inventory on hand and extending to its lessees an option to buy on reasonable terms, subject to fulfilling any existing lease obligations running to lessees undesirous of exercising the purchase option. Or, a court could resolve these issues by enjoining the utility from 
entering the SHAC market and requiring the state energy commission to assist manufacturers in processing their systems through the state's testing program for a reasonable charge.

\subsubsection{Utility Nonentry into the SHAC Market}

Without entering the SHAC market, a utility can still use its monopoly power to harm competitors in that market. An obvious abuse would be the utility's refusal to supply back-up power to customers within its service area using SHAC systems as their primary source of heating and cooling. Such refusals not only contradict Sherman $\$ 2$ standards, they also violate the utility's statutory duty to provide just, reasonable, and adequate service to all potential customers within its service area.

'The general principle established in United States v. Colgate [253] is that:

[i]n the absence of any purpose to create or maintain a monopoly, the [Sherman Act] does not restrict the long recognized right of [a] truder or manufacturer .... to exercise his own independent discretion as to parties with whom he will deal. [254]

However, unilateral refusals to deal have been struck down when used in an effort to monopolize or to extend an existing monopoly position [255]. Because the utility's refusal to supply results in a foreclosure of market alternatives for the consumer, the need to allege and prove specific intent or purpose is obviated [256]. If such refusals were allowed, potential purchasers of SHAC systems would tend to rely on the utility for full service rather than purchase a solar appliance and be forced to provide an alternative back-up supply themselves. Consequently, total sales in the relevant SHAC market would decrease and the utility's monopoly power would be entrenched. Such results are clearly the type of market effects that the antitrust laws were intended to prevent.

Predatory pricing policies used to gain or hold monopoly power were identified very early in the case law of antitrust as conduct that violated Sherman \$2 [257]. A firm that holds monopoly power by virtue of ownerhip of a unique resource, such as an electric utility, is guilty of monopolization if it exploits that resource in ways which exclude or disadvantage customers arbitrarily or capriciously. This "public utility" standard imposed on lawful monopolists requires the utility to have a rational and relevant basis for any distinctions in prices charged [258]. To the extent that providing intermittent service to users of SHAC devices costs the utility proportionately more than the cost of continuous service to other customers, price distinctions will be lawful. However, charging the solar customers a price that exceeds the utility's proportionate cost increases constitutes ärbiträry and discrıminatory pricing that violates Sherman $\$ 2$ [259].

An equally suspect arrangement would involve a utility's requirement that its customers desiring to use SHAC units with utility back-up service available purchase the SHAC units only from specified manufacturers. A utility's motivation for such an arrangement might be based either on legitimate concerns for safety, efficiency, or standardization, or on anticompetitive intentions arising out of some special relationship with the designated manufacturers.

The FTC has instituted proceedings under Section 5 of the FTCA, in which "coercive" use of purchasing power similar to the hypothesized requirement that SHAC equipment be purchased only from designated suppliers, was challenged as an unfair method of 
competition [260]. Because a foreign element is introduced into the open market, purchasers' freedom to choose among competing suppliers is curtailed, and potential sales by the participants' competitors are unfairly diverted.

A tying arrangement between utility back-up service and utility-specified SHAC systems could also be challenged by excluded SHAC manufacturers under Clayton $\$ 3$ or Sherman \$1. As a threshold jurisdictional matter, the Clayton Act provision applies only to arrangements in which both the "tying" product (back-up electricity) and the "tied" product (SHAC systems) are tangible commodities. Although the case law is conflicting, electricity has been so characterized [261]; SHAC systems, as yet unadjudicated, are unquestionably tangible goods. In any event, the Sherman Act reaches the services or intangibles outside the scope of the Clayton Act.

Courts have repeatedly held that tying arrangements are suspect under both acts because they "serve hardly any purpose beyond the suppression of competition"[262]. Under either act tying arrangements are judged by a qualified per se rule. Pure per se rules foreclose market analysis-if defendants engage in price-fixing activities, their conduct is per se illegal regardless of their market power or the effect of their behavior on competition-whereas the qualified per se rule applicable to tying arrangements takes market power and market effect into consideration, and the fact of the tie-in alone will not invoke a per se ruling.

In Times-Picayune Publishing Co. v. United States [263], the Supreme Court stated:

When the seller enjoys a monopolistic position in the market for the "tying" product, or if a substantial volume of commerce in the "tied" product is restrained, a tying arrangement violates the narrower standards expressed in $\$ 3$ of the Clayton Act because from either factor the requisite potential lessening of competition is inferred .... [A] tying arrangement is banned by $\$ 1$ of the Sherman Act whenever both conditions are met. [264]

Thus, under Times-Picayune, a tying arrangement per se violates $\$ 3$ of the Clayton Act only if the requisite market power or market effect is proven, and the arrangement is a per se violation of Sherman $\$ 1$ only if both power and effect are proven.

If a tie-in between utility back-up service and utility specified SHAC systems met the jurisdictional commodity requirement under the Clayton Act, the utility's monopoly power in the tying market (back-up electricity) provides a simple basis for a per se finding of illegality under the Times-Picayune Clayton Act test. The utility might escape per se liability by showing that suitable alternatives to its services are available, thereby rebutting the presumption of monopoly power in the tying market [265]. Under present circumstances, such a suggestion may be mere sophistry, but technological developments may indeed provide realistic alternatives to utility back-up services.

If the court declines to view electricity as a commodity under Clayton $\$ 3$, the applicable Sherman Act test under Times-Picayune would require, in addition to proof of market power, a showing that a substantial amount of commerce in the tied market (SHAC systems) is restrained. Case law indicates that this second element is satisfied by showing that a not insubstantial dollar volume of commerce in the tied product has been affected by the tie-in. This showing of effect is required because the focus of concern is the foreclosure of competitors from the tied product market [266]. An amount as little as $\$ 60,800$ has been viewed as "not insubstantial" for purposes of illegality [267]. 
If the effected dollar volume in the tied SHAC system market is insufficient to satisfy this second requirement for a per se ruling under the Sherman Act, a plaintiff might still be able to prove a violation of Sherman \$l under general rule of reason standards. Rule of reason analysis requires the court to consider whether the benefits or justifications alleged by the defendants are such as to validate the arrangement when weighed against the competitive injury [268]. However, the prevailing modern conception of the rule identifies impact on competition as the sole measure of legality [269]. The flexibility afforded by the rule does allow the court to judge degrees of competitive injury or to weigh the competitive harms and benefits of the practice. But, if the net effect of the restraint will significantly impede competition, complementary social gains cannot be placed on the scale.

Under a rule of reason analysis, the utility may defend the hypothesized tie-in by presenting evidence that the designated manufacturers' SHAC equipment is more reliable and efficient than the plaintiff's' equipment, and consequently helps the utility to predict its service load. If the plaintiffs failed to rebut such utility allegations and the utility had no economic interest in the approved manufacturers' business, the utility's justification might convince the court that the goals of competition are served by so stimulating the product improvement necessary to participate in the arrangement.

Additionally, notwithstanding the per se language in many of the tying cases, courts have considered whether the arrangement was the result of legitimate business practices. U.S. v. Jerrold Electronics Corp. [270] stands for the proposition that:

[a]ny judicially ... . declared per se rule is not conclusively binding on this Court as to any set of facts not basically the same as those in the cases in which the rule was appplied..... Therefore, while the per se rule should be followed in almost all cases, the Court must always be conscious of the fact that a case might arise in which the facts indicate that an injustice might be done by blindly accepting the per se rule. [271]

Application of the flexible rule permitted the defendant in Jerrold to engage in the restraints for a limited period of time, even though under Sherman $\$ 1$, the standard of sufficient "economic power" in the tying product was easily satisfied. The key to the Court's liberal approach was

the fact that the tie-in was instituted in the launching of a new business with a highly uncertain future ..... Interest would wane rapidly if the systems installed did not consistently produce satisfactory results. Not only Jerrold's reputation but the growth of the entire industry was at stake during the development period. [272]

The Court considered whether less restrictive alternatives, such as selling the equipment on a piece by piece rather than full system basis or offering service contracts on a voluntary rather than compulsory basis, could have accomplished the same desired ends. Because of the newness of the industry, the practical need for custom-made systems, and the technical knowledge and skill required to properly assemble, install, and service the equipment, the Court concluded that the defendants' policies of selling only full systems in conjunction with a service contract were reasonable and lawful at the time of their inception. However, "as the industry took root and grew, the reasons for the blanket insistence on a service contract disappeared ... and the economic reasons for selling complete systems were eliminated" [273]. 
The Jerrold opinion describes current conditions in the SHAC industry; new business, uncertain future, fear of inconsistent performance results, growth of entire industry at stake, and proper assemblage, installation, and servicing. Clearly, the SHAC system manufacturers could avail themselves of the Jerrold defense under present market conditions. Whether the defense would apply equally to the utility is an open question. If the defense hinges on the defendant's economic interest in the new products' market success, the utility could seek refuge under the doctrine if it was directly engaged in the manufacture and sale of SHAC systems. Yet, a utility that enters a horizontal unregulated market risks violation of Sherman \$2. Perhaps the underlying rationale in Jerrold is better stated in terms of the defendant's interest in assuring the proper functioning of the new equipment. The opinion does stress the future of the emerging industry rather than the commercial success of the individual company defendant. Such a reading of the Jerrold doctrine ought to justify the utility's conduct, at least where the argument is based on a bona fide need for reliable primary heating and cooling systems within the regulated service area, and not a monopolistic intention to restrict competition in an ancillary market.

Short of actually entering the SHAC market, it has been shown that a utility can use its market power to substantially harm competition in the SHAC industry. The same monopoly power may be used, conversely, to exert a procompetitive effect on the relevant SHAC market to the economic detriment of third parties. Suppose a utility charges all of its customers-SHAC users requiring costly intermittent back-up service and full utility users whose consistent demand levels are proportionately less costly to provide-the same price. Applying the "public utility" standard to such a pricing scheme indicates that the conduct would be unlawful, because such spreading of losses among all customers is as arbitrary as the predatory pricing practices discussed earlier. The main distinction lies in the effects of the conduct. Charging all customers a single rate would create some incentive to purchase SHAC systems, assuming that the expectation of proportionately higher utility bills was perceived by consumers as a barrier. Under these circumstances, the potential plaintiffs would be the utility's shareholders, the utility's suppliers, and the utility's nonsolar customers. The shareholders and suppliers would be injured by a loss of overall profits in the long run (given the increased conversion to SHAC), and the nonsolar customers would be injured by the increased price of services that is not reflective of costs.

In addition to any claim based on the utility's statutory duties, invocation of the antitrust public utility theory would support a Sherman $\$ 2$ claim based on illegal price cutting. Alternatively, a plaintiff might seek relief under state antidiscrimination statutes. Such laws are sometimes patterned after the federal price discrimination statute; the Robinson-Patman Act (Clayton \$2). The need to pursue the claim at the state level arises because the Clayton $\$ 2$ "in commerce" language has been construed as requiring proof that at least one of the sales which established the price discriminator was an interstate sale [274]. The Supreme Court endorsed this rigorous application of the "in commerce" requirement in the Robinson-Patman Act in Gulf Oil Corp. v. Copp Paving Co. [275]. Rejecting the "nexus" approach to commerce and the argument based on the full scope of Congress' commerce power, the Court affirmed the interpretation that Clayton $\$ 2$ applies only where "at least one of the two transactions which, when compared, generate a discrimination ... cross[es] a state line" [276].

Because a state-regulated utility does not engage in retail sales that cross state lines, the Robinson-Patman Act is inapplicable to the utility retail market. Additionally, the statute is limited to purchases of commodities, and the cases have uniformly interpreted the language to mean tangible, physical, movable goods. Although at least one court has 
construed the word "goods" to include electricity [277], the majority of cases have excluded borderline "goods" from the scope of the Clayton Act [278].

Reference to state law does not clarify the issue. Clearly, the in-commerce requirement is obviated at the state level, but whether the state laws have expanded the jurisdictional "commodity" requirement that potentially excludes electricity cannot be generalized. In any event, the alternative claim for relief available under Section 2 of the Sherman Act presents no jurisdictional problems and may be successfully invoked against a utility engaged in price discrimination (where monopoly power is present).

\subsection{COMPETITIVE IMPACT OF SMALL BUSINESS INVOLVEMENT IN SHAC INDUSTRY}

A major theme throughout the past two sections has been the significance of size as an "earmark of monopoly power" [279]. Because the objectives of antitrust làw are to promote competition and prevent undue concentration, the law generally treats large entities more harshly than small entities.

\subsubsection{Pro-Small Business Legislation}

In addition to the various antitrust laws previously discussed, Congress has attempted to prevent an overconcentrated economy through various statutes intended to promote the survival of small enterprises. An important example is the Small Business Administration (SBA) established by Congress [280] to aid "small-business concern[s]" which the enabling statute defines as any entity "which is independently owned and operated and which is not dominant in its field of operation" [281]. SBA's programs include small-business loans, grants for studies, subcontracting programs, aid in procurement, studies of federal programs and recommendations for program changes to agencies, aid in research and development, and pooling arrangements exempt from antitrust laws.

An SBA employee works with the Small Business Office of DOE's Division of Procurement to suggest the appropriate steps for small business participation in solar programs. Small business representation in this process is buttressed by a provision in the Energy Reorganization Act of 1974, which calls for the provision of reasonable opportunities for small business participation in solar programs, and consultation by DOE with the SBA [282]. Additionally, federal agencies are required by statute to provide "realistic and adequate" opportunities for small firms to participate in SHAC demonstrations [283].

These legislative mandates are apparently being carried out; at least to the extent that federal solar contracts are capable of fulfillment by small firms engaged in SHAC system or component manufacturing. ERDA reported that $40 \%$ of the Solar R\&D dollars in FY 76 was allocated to small firms, and the percentage of SHAC dollars was reported to be even higher [284]. In HUD's commercial demonstration program, the first cycle's project had "significant small business participation" which "increased to $90 \%$ [participation] in the second cycle" and approached "100\% in the residential program" [285].

Whether small businesses will enjoy the same degree of participation in thermal storage $R \& D$ remains to be seen. The insufficient funds (about $1 \%$ of DOE's FY78 budget) that have been devoted to the storage program, provide a weak basis for drawing inferences regarding the identity of future contractees. However, the fact that most systems require fairly technical $R \& D$, coupled with the systems' high costs [286], suggest that universities, government laboratories, or large firms equipped with laboratories will be 
the recipients of government storage contracts. Private funds of large firms may also be devoted to storage $\mathrm{R} \& \mathrm{D}$.

Once an economical and feasible storage system is developed, as indicated earlier [287], those firms able to manufacture a packaged SHAC/storage system will have a competitive edge because the need for back-up electric or gas heat will be obviated. If small firms are ill-equipped to perform the $R \& D$ work, this competitive disadvantage will likely leave them similarly situated regarding the ultimate manufacturer. Small firms manufacturing storageless SHAC systems will, therefore, have to purchase storage equipment from their competitors to market a complete unit; to price the unit competitively, they will have to realize a lesser profit.

Because present market knowledge regarding storage technology is highly imperfect, the possibility exists that the most "useful" storage system ultimately designed will be patentable as relying on a "new ... process, machine, manufacture, or composition of matter, or any new and useful improvement thereof" [288]. Inventions meeting this criteria may be granted a patent if the inventor is the first to reduce the invention to practice [289], where the invention is nonobvious [290] and has utility [291]. The patent allows the inventor "the right to exclude others from making, using, or selling the invention ..." [292] for 17 years, in return for which the inventor must fully disclose the invention [293].

The competitive advantage of obtaining such a monopoly-by patent-does undercut antitrust policy. But the patenting system has a constitutional basis [294] and is tolerated because of a belief that reliance on free market forces alone will not generate the socially optimal investment in innovation. Thus, the patent system encourages innovation in a free market setting by granting an exclusive property right [295] to the inventor.

The obvious tension between antitrust and patent policies was originally resolved in favor of the patent. As in other areas of the law arguably exempted from antitrust scrutiny, case law over the last few decades has tended to prefer antitrust law over patent law when conflicts have arisen [296]. Where misuse of a patent; i.e., expanding the patent monopoly beyond the permitted scope, once merely precluded the patentee from enforcing the patent [297], in 1944 the Supreme Court recognized patent misuse as a basis for affirmative relief under the antitrust laws [298].

Because of the competitive significance of storage systems in the SHAC industry, the manufacturer that obtains a patent for a "new and useful" storage process or product will enjoy 17 years of monopoly power in the relevant market absent other restrictive or anticompetitive conduct. Small firms sensitive to this opportunity, but individually lacking in resources, may wish to pool their resources and efforts to develop an efficient and economical form of storage. Although such horizontal alignment among competitors is a classic violation under Section 1 of the Sherman Act [299], joint research activities are not per se illegal because innovation is supported by public policy (i.e., the Patent Code). In fact, the SBA has authority to approve joint R\&D agreements between smallbusiness concerns, subject to the approval of the FTC and the permission of the Attorney General. By statute, conduct within the scope of an approved agreement will not violate the antitrust laws [300]. Although the opportunity has not been exploited since World War II, when the antitrust exemption was broader [301], the continued existence of a similar, albeit narrower exemption is further evidence of the congressional policy to encourage innovation even if it means relaxing antitrust standards. 


\subsubsection{Joint Research Activities}

Case law directly addressing joint research among competitions is scarce. However, a reading of available authority [302] suggests that the activity would be judged by a rule of reason standard. The Court would evaluate competitive harms and benefits in light of the prevailing economic conditions and the structure of the industry.

Notwithstanding the competitive conditions that characterize the SHAC industry, the relevant submarket in thermal storage is restricted by fairly high entry barriers because of the expenses and risks associated with the $R \& D$ required to perfect a storage system. Because of the interdependence between the relevant SHAC and storage markets, fostering competitive conditions in the storage market is crucial to maintaining competition in the SHAC market. Solar $R \& D$ performed with government funds is subject to a restrictive patent policy [303]. Therefore, larger firms will prefer using private funds on thermal storage $R \& D$. Because such private efforts, if successful, may generate patents likely to produce monopolistic conditions in the broader SHAC industry, joint action by smaller firms should be tolerated.

Conversion to solar is a matter of public policy, and removing the need for utility backup service that presently impedes widespread use of SHAC systems furthers that policy. In Appalachian Coals v. U.S., a Supreme Court case decided during the Depression, the Court held that even though competitors' joint sales agency agreements might be construed as a per se illegal price-fixing agreement under normal circumstances, because of "deplorable economic conditions in the [coal] industry ... realities must dominate the judgment. The mere fact that the parties to an agreement eliminate competition among themselves is not enough to condemn it" [304]. The Court found that the purpose of the agreement was to counteract the "destructive practices" of more powerful producers by creating the potential for "better methods of distribution ... intensive advertising and research, to achieve economies in marketing" [305]. Therefore, the producers' attempt to remedy stressful conditions in the industry through collaboration was appropriate [306].

Although the weight of post-Appalachian case law treats horizontal price-fixing combinations much more harshly [307], language in Appalachian as well as subseguent cases [308], suggests that some basis for inferring the market power of the defendants to affect prices should exist before finding the combination illegal. Furthermore, contemporary cases provide some authority for pointing to energy crises and environmental dangers as justification for cooperative action [309]. Thus, resurrection of the Appalachian rationale seems appropriate in the solar energy context. An argument based on overriding economic circumstances and structural conditions of the industry may persuade the Court to apply a rule of reason analysis to small SHAC firms' joint $R \& D$ activities. This will trigger an evaluation and a weighing of the arrangement's competitive harms and benefits, and a determination as to whether less restrictive alternatives are available [310].

At least three potential benefits of joint $R \& D$ activities may be identified under the rule of reason. First, "scale economies may be achieved which make it feasible to carry out projects beyond the reach of any of the participating firms acting alone" [311]. Because of the industrial structure and conditions in the SHAC market, such research may be essential to the small firms' continued survival and the prevention of oligopoly or monopoly. Second, "wasteful duplication may be avoided by joint research" [312]. The efficiency value underlying antitrust policy is particularly significant in the $R \& D$ context. Whereas the resources expended by firms acting independently to produce duplicative 
SHAC equipment are not wasted because each separate product has a purchase value, duplicative $R \& D$ work that culminates in the same idea is resource wasteful because the invention does not have the same doubled market value. Third, "joint research may of ten be carried out in ways that facilitate a wider distribution of technology than would result from research conducted by a single firm" [313]. All participating firms would have access to the $R \& D$ output on a nondiscriminatory and reasonable basis in contrast to the inaccessibility of a single firms's R\&D output.

On the negative side of the rule-of-reason scale, at least three factors may also be recognized. First, competition resulting from independent action "can be a spur to efficiency in research . . . [because] jointness may substitute a large, lazy research program for several individual programs at least some of which are spare and imaginative" [314]. Competiting $R \& D$ work may pursue different areas and produce different results. Second, "joint activity may reduce total research investment to a level below that which would be sustained if joint programs were inhibited" [315]. Some of the incentive to aggressively pursue $R \& D$ would be lost because participants no longer would have the potential for exclusive rights in the output, although in the SHAC industry, this concern could be lessened by small firm perceptions of vulnerability of combined market power. Finally, if the joint researchers represent all or most of the firms in a market, the dangers loom larger [316]. Considering the competitive implications of introducing storage into the SHAC industry, the issues raised by the positive and negative effects suggested previously should be resolved in favor of the joint activity, so long as the combined market share of the participants does not reach a suspect level [317].

Patent policy is, by statute, significantly different when the "new and useful" idea is a result of government-funded solar RD\&D. Pursuant to Section 9 of the Federal Nonnuclear Energy Research and Development Act of 1974 [318], DOE (formerly ERDA) generally takes title to all patented inventions made possible by DOE/RD\&D contract dollars. DOE grants only revocable, nonexclusive licenses to the inventors for their work product [319] and retains the power to license its patents to others [320].

If an antitrust attack was made on the type of $R \& D$ pooling agreement described in the preceding paragraphs, and plaintiffs could show that government contract work had produced a storage system subject to a government patent, such patent licensing could be a less restrictive alternative to the normal private patents obtained via joint $R D \& D$ agreements. It is difficult to imagine any bona fide circumstances under which the joint $R \& D$ would continue, unless defendants could show that their expected output would materially differ from the government's patent. In analogous situations, the guiding inquiry has been whether the technology controlled by the pooling arrangement controls otherwise unavailable technology, where such technology would assist nonmembers who seek to enter or compete in the relevant market [321]. If, as in the situation herein, reasonably functional substitutes are available to outsiders, then as long as the aggregate market share of the pool does not reach such a proportion that substantial adverse impact on competition may be inferred, the pool may be lawful under the Sherman Act rule of reason [322].

On the other hand, the arrangement may be analyzed as a joint venture under Clayton $\$ 7$, and therefore, subject to the "tendency to substantially lessen competition" standard. The pool's market share may fall short of Sherman Act monopoly power, yet still rise to the level of an incipient monopoly under the Clayton Act. If so, complete divestiture of the joint arrangement may be unfair, and the Court has the discretionary powers to fashion a more equitable decree. For example, "[m] andatory selling on specified terms 
and compulsory licensing at reasonable charges are recognized antitrust remedies" [323]. Depending on the identity of the patentees, licensing may be ordered on a royaltyfree basis or at reasonable royalties [324].

\subsubsection{Miscellaneous Horizontal Arrangements Among SHAC Enterprises}

Any cooperation between businesses at the same levol of distribution in a particular industry, is considered a "horizontal" arrangement for purposes of antitrust analysis. When horizontally aligned small firms combine efforts toward a common goal, their conduct is suspect under the antitrust laws, for two basic reasons. First, if the combination brings a substantial part of a relevant market under common control, the reduction of competition approaches monopoly conditions [325]. Sccond, even if the combinution's market power falls appreciably short of monopoly, cooperation among compctitors is inconsistent with the unrestricted market setting that is at the core of untitrust thenry [326].

Although collaboration among competitors falls squarely within the Sherman \$l language that prohibits combinations in restraint of trade, such horizontal arrangements may have procompetitive effects on the market, and therefore, are analyzed generally under the rule of reason. Price fixing among competitors, however, is consistently held to be per se illegal. Horizontal group boycotts and division of markets are also very highly suspect, of ten constituting per se illegal activity.

In general, the per se line of reasoning does not tolerate any cooperation among competitors and is invoked when the subject of the arrangement is or has an effect on prices. Such arrangements are so inconsistent with the competitive modcl that the arrangentuls are "conclusively presumed to be unreasonable and therefore illegal" [327]. Tor example, in United States v. Socony-Vacuum Oil Co. [328], the Supreme Court stated that "[a]ny combination which tampers with price structures is engaged in unlawful activity" [329]. Evidence in Socony-Vacuum that the competitors' agreement on markot prices was an effort to counteract the ruinous price-cutting activities of powerful competitors could not justify the price-fixing combination because:

to the extent that they raised, lowered, or stabilized prices they could be directly interfering with the free play of market forces. The [Sherman] Act places all such schemes beyond the pale and protects that vital part of our economy against any degree of interference. [330]

'I'his language reflects the centrality of price competition in antitrust policy. Even when competitors agree or confer on nonprice aspects of their businesses, if the proven purpose or effect of the conduct has a chilling effect on price competition, the agreement is tantamount to price fixing and is likely to come under the per se rule. In the words of Justice Douglas, "Price is too critical, too sensitive a control to allow it to be used even in an informal manner to restrain competition" [331].

Horizontal combinations are also subject to per se rules if the object of the arrangement is to exclude competitors [332]. Courts will carefully scrutinize a horizontal combination if it represents such a substantial portion of the market that the group as a whole is in substance a monopoly power. This domanance will be presumed unreasonable if acquired through unreasonable trade practices, maintained through exclusionary activities, or (as in the case of overwhelming domanance) through "unnatural" business practices [333]. Thus, in Fashion Originators' Guild of American, Inc. v. FTC (FOGA) [334], a guild of clothing manufacturers agreed that they would refuse to sell to retailers who also sold 
garments copied from Guild member designs. Because FOGA's market share was substantial and the agreement was-by the Guild's admission-aimed to eliminate troublesome competitors, the Court applied a per se rule of illegality to find the boycott offensive under the Sherman Act.

Most small SHAC firms are members of the Solar Energy Industries Association (SEIA). Like many trade associations, it ostensibly serves various legitimate purposes, including the exchange and dissemination of information. Antitrust policy regarding communications among small firms, as in the case of SEIA members competing in the SHAC market, is faily well-settled. Two prototypical varieties of horizontal restraints, closely related to price fixing and boycotts, are "data dissemination" and "standardization" programs. If competitors regularly communicate price-sensitive information, under certain circumstances the activity may be viewed as a camouflage for an underlying price-fixing scheme; restraint by data dissemination. Similarly, if industry standards or association memberships are based on criteria that unreasonably discriminate against certain competitors, this "standardization" may be tantamount to a boycott.

The threshold determination in a horizontal restrain involving informational exchanges includes identifying the relevant market and the defendants' share therein, and a structural assessment of industry conditions. In analyzing activities of SEIA, the relevant market at the present time is SHAC system manufacturing. The related thermal storage market will exert an increasingly important competitive pressure on the relevant market. Therefore, the organizational diversity, ease of entry, large number of competitors, near-perfect market knowledge, and other earmarks of a competitive structure that characterize the SHAC industry will begin to erode as storage enters the market. Eighty percent of SEIA's members are classified as small businesses [335], and membership is apparently nonexclusionary, excepting the requirement that applicants be engaged in some aspect of the solar energy industry. However, the entire SEIA membership is probably not party to all types of informational exchanges regarding the SHAC industry.

Because SHAC is the primary solar technology that is actually "on the market," the government and public want to be informed of developments, economic feasibility studies, sales figures, production figures, and countless other details. Under these conditions, it is only reasonable to place responsibility on an association like SEIA to represent individual firms in reporting such detailed information as required by the government or the public. By the same token, it is foolish to assume that these same firms are not taking advantage of available information. A respected antitrust scholar has observed:

The wide and rapid dissemination of price and related information is one of the prerequisites for a competitive market. If most of the other prerequisites (most importantly a large number of buyers and sellers, none with a substantial market share, and a nondifferentiated product) are present, the tendencies toward competitive behavior can be expected to be strong; adding the preréquisite of widespread information can be expected to make the market work more competitively. [336]

Because the data dissemination is presently required and carried out by federal agencies, and especially in light of the highly competitive conditions in the SHAC industry, informational exchanges in SEIA presently provide no basis on which to claim that small members have conspired to fix prices, exclude competitors, or gain a substantial portion of the market. Of course, recent Supreme Court decisions do seem to deny relief from 
the antitrust laws based solely on the fact that the government required the conduct [337]. However, even absent any immunity, structural conditions are such that the SEIA data dissemination activity does not support a Sherman Act violation.

Present SHAC standard setting appears to be similarly procompetitive, although for different reasons. The most recent DOJ statement regarding standardization [338] indicates that antitrust concerns will not be raised so long as the standards-setting process ( 1 ) is open and provides due process, (2) allows for meaningful participation by a balanced cross section of all affected parties, and (3) provides a mechanism for appeals, unless the resulting standardization "unduly limits the competitive process" [339]. With respect to the SHAC industry, standards-setting activity has been directed at developing technical criteria by which new components, such as collectors, may be judged. This standards development has occurred within the existing "voluntary consensus system" that pre-dates solar energy commercialization. The procedures involved conform substantially to the antitrust standards referred to previously [340].

Much of the case law regarding anticompetitive standardization pre-dates comprehensive governmental antitrust policy statements on standards-development procedures. Since the issuance of these statements, "United States standards organizations . . . have made substantial efforts to adopt proper procedures and rules that take competitive issues into account" [341]. No immunity is conferred by the adherence to policy guidelines [342] or the quasi-official standards organizations' supervision [343], however, the standards organizations have purportedly altered their procedures to circumvent the antitrust problems that have arisen in the past [344]. Assuming compliance with the guidelines, short of a direct attack on the reasonableness of a given standard, in all probability the SHAC standards-development process could withstand antitrust scrutiny.

A final type of horizontal activity that may violate the antitrust laws is mergers between competitors. Under Section 7 of the Clayton Act, industrial concentration levels and structural trends weigh heavily in the courts' determination [345]. Additionally, because any horizontal merger by definition removes a competitor from the market, an antitrust violation requires a lesser showing of concentration or movement towards combinations than for other merger types.

Under present conditions, if two small SHAC manufacturers merged, the market evidence available suggests that the marriage may be procompetitive or at least preventive of destructive competition. The same benefits asserted in favor of joint research activities [346] would be applicable here-scale economies, avoidance of duplication, and wider distribution of technology. In the production context, desirable economies of scale and avoidance of duplication may be achieved through mergers between small firms. The internal expansion altenative that is preferred when an entity is already large or the market is trending towards concentration is, at least in theory, to be disfavored when the entity is small and the market competitive. In such cases, a horizontal merger between two small firms may allow both entities to remain in business. Preventing the merger may force each entity to become overly aggressive and creates the potential for destructive competition. Ultimately, certain firms will drop out, and resources expended in the race will be wasted.

The wide distribution of SHAC technology will predictably occur whether or not small firm mergers are allowed. However, each report of a solar firm going out of business, possibly failing to honor its obligations, reinforces consumer mistrust for the innovative technology. As a practical matter, such sentiments must be replaced with confidence in 
the SHAC firms' stability if national energy goals are to be realized. Therefore, mergers among small SHAC firms ought to be tolerated, at least until market share data or merger trends reach suspect levels.

The weight of authority is against horizontal mergers, even between firms with fairly modest market shares and in industries with nonsuspect concentration levels. However, in most of these cases there has been some evidence of a trend towards concentration, however weak or slow [347].

Remembering that the basic standard applicable to such a merger is whether it would produce a firm controlling an "undue" share of the market and would increase concentration "significantly" [348], the cases suggest that a prima facie case is easily established. U.S. v. Von's Grocery [349] is a good example of the Court's tendency to react negatively to horizontal merger where there is even a slight trend towards concentration in the industry, despite relatively low market shares and concentration ratios. In Von's Grocery, the largest firm in the relevant geographic market had an 8 percent market share, and the two merging firms each had less than 5 percent. Prior to the merger, the top four-firm concentration ratio was over 24 percent and the post-merger figure would have approached 29 percent [350]. These modest market shares and relatively low concentration ratios indicate the absence of suspect statistics according to DOJ guidelines [351]. These guidelines indicate that a 4 percent plus 4 percent Von's-type merger would typically be suspect only if the four-firm concentration ratio were 75 percent [352], and yet in Von's the ratio was less than 25 percent. The Court held the merger unlawful because there was a decrease in the number of independent units in the relevant market over a ten-year period. In addition, the parties to the merger were rapidly growing firms. That the Court was persuaded by concentration levels in the industry rather than by the market shares of the parties at hand, is supported by DOJ guidelines. In addition to the standards quoted above, the merger guidelines also suggest that where even a slight trend towards concentration is established in a given industry, any merger that increases the share of any significant firm by $2 \%$ will be subject to challenge [353].

Without reference to statistics for the SHAC industry, conclusive analogies cannot be made. The industry has already begun to experience the beginnings of a trend towards concentration. Acquisitions, subsidiaries, and joint ventures have taken place [354]; and unprofitable firms have gone out of business [355]. Because horizontal mergers are judged by a limited per se rule-couched in language that calls for exculpatory market statistics[356] - the courts are likely to tolerate such mergers between SHAC firms with small market shares, at least for the present and near future. 
SEP燐 


\section{SECTION 5.0}

\section{CONCLUSIONS}

Many industry observers and solar equipment producers view the commercialization of SHAC as an opportunity to undermine the market dominance now enjoyed by energy companies and electric utilities. Whether their hopes will be realized depends on Congress' posture towards interenergy diversification and DOE's spending practices. Current congressional attitudes have been permissive of such diversification and relatively insensitive to competitive consequences. Ultimately, emergence of a competitive SHAC industry that includes small firms, depends on the Supreme Court's willingness to aggressively interpret the antitrust laws-which is likely, given recent holdings.

Notwithstanding the legislative and administrative branches' tacit compliance with entrenched firms' involvement in SHAC, and the various other solar energy submarkets; injured businesses, consumers, DOJ, and the FTC have the opportunity to force the controversy onto the judiciary by bringing suit under the antitrust laws against companies displaying anticompetitive market practices.

As a matter of public policy, facilitation of solar energy commercialization by utility and energy companies-with their capital resources, managerial expertise, and technologcial knowledge-must be weighed against the possibility that such involvement by those firms will retard the commercialization process because interchangeability between end uses of renewable and nonrenewable energy resources creates opportunities and motives for market manipulation.

Even assuming there are immediate benefits to be gained from entrenched firms' efforts to commercialize solar, long-term impacts on the structure of the emerging solar industry must be considered. Inasmuch as organizational diversity is an economic and social value, the antitrust laws may be enforced to prevent any large firm from dominating the solar industry where such involvement has a proven anticompetitive purpose or effect. Even small firms may violate antitrust policy, especially when they collaborate horizontally in price-sensitive or exclusionary activities.

Utilities' regulated monopoly status complicates application of the antitrust laws. Recent Supreme Court cases have rejected the notion that economic regulation of an industry bars enforcement of the antitrust laws. The extent to which utilities can now safely enter unregulated markets is unclear. However, the trend is unmistakably towards stricter scrutiny of regulated entities' market practices.

Still, antitrust policy and enforcement is not a panacea. Its philosophical underpininings are keyp. to basic competitive models, and the courts are equipped to interpret the law to accommodate new market circumstances. However, excepting the actual commercial activity in the SHAC submarket, the broader solar energy industry is presently at a stage that is beyond the reach of antitrust law enforcement. Unless legislative changes are made, or the DOE develops a more aggressive competitive energy policy, the courts will continue to promote competition in and among the various energy markets on a case-bycase basis, but only with regard to functioning commercial activities. 


\section{SझPl}




\section{SECTION 6.0}

\section{REFERENCES}

1. See generally Public Utility Regulatory Policies Act of 1978, Pub. L. No. 95-617, 92 Stat. 3117 (1978); Energy Tax Act of 1978, Pub. L. No. 95-618, 92 Stat. 3118 (1978); National Energy Conservation Policy Act, Pub. L. No. 95-619, 92 Stat. 3206 (1978); Power Plant and Industrial Fuel Use Act of 1978, Pub. L. No. 95-620, 92 Stat. 3289 (1978) and; Natural Gas Policy Act of 1978, Pub. L. No. 95-621, 92 Stat. 3352 (1978).

2. See United States v. Philadelphia National Bank, 374 U.S. 321, 338 (1963). (hereinaf ter US v. PNB)

3. See generally L. Sullivan, Handbook of the Law of Antitrust 1-6 (West, 1977); P. Areeda, Antitrust Analysis 17-18 (Little, Brown and Co., 1974).

4. 15 U.S.C.A. $\$ \$ 1-7$ (1976 and Supp. 1978).

5. 15 U.S.C.A. \$12-17 (1976 and Supp. 1978).

6. 15 U.S.C.A. $\$ \$ 41-58$ (1976 and Supp. 1978).

7. See National Labor Relations Board v. Jones \& Laughlin Steel Corp., 301 U.S. 1 (1937); Heart of Atlanta Motel v. United States, 379 U.S. 241 (1964).

8. E.g., Apex Hosiery Co. v. Leader, 310 U.S. 469, 485 (1940); United States v. Socony-Vacuum Oil Co., 310 U.S. 150, 224 n. 59 (1940).

9. The discussion which follows borrows heavily from Sullivan, Antitrust 22-29 (West, 1977). Readers unfamiliar with the economic models are encouraged to consult Sullivan's text for in depth explanation beyond the scope of this article.

10. White House Task Force Report on Antitrust Policy (1968) (The Neal Report), reprinted in 2 Antit. L. and Econ. Rev. II (Winter 1968).

11. An overview of contemporary antitrust doctrine is presented. The concepts will be developed more fully as they arise in the context of the solar heating and cooling industry and broader energy market. Readers familiar with antitrust law may wish to pass over this section.

12. See notes 4,5 and 6 supra.

13. 15 U.S.C. $\$ \$ 1-2(1976)$.

14. U.S.C. $\$ \$ 14,18$ (1976).

15. S. Rep. No. 698; 63d Cong., 2d Sess. 1; H.R. Rep. No. 1191, 81st Cong., 1st Sess. 8; S. Rep. No. 1775,81 st Cong., 2d Sess 4-5. See U.S. v. E. I. du Pont de Nemours \& Co., 353 U.S. 586,589 (1957).

16. 15 U.S.C. $\$ 45$ (1976).

17. For a good discussion on the scope of FTCA $\$ 5$ see Federal Trade Comm. v. Sperry and Hutchinson Company, 405 U.S. 233 (1972).

18. 15 U.S.C. $\$ 45$ (1976). Federal courts have historically found that no private action could be implied from the FTCA. E.g., Holloway v. Bristol-Myers, 485 .F. 2d 986 (D.C. Cir 1973); Carlson v. Coca-Cola Company 483 F. 2d 279 (9th Cir. 1973). However, in Guernsey v. Rich Plan of the Midwest, 408 F. Supp 582 (D.C.N.D. Ind. 
1976) the court distinguished prior case law on the basis that the FTC's jurisdiction "has been held to be primary rather than exclusive." Id. at 588. The court therefore held that the private plaintiffs' allegation that they had been victimized by defendant's deceptive practices and acts and unfair methods of competition was sufficient to state a claim for relief under the FTCA. Id. at 576-89.

19. 15 U.S.C. $\$ 15$ (1976).

20. 15 U.S.C. $\$ 4, \$ 15 a(1976)$.

21. 15 U.S.C. $\$ 21$ (1976).

22. 15 U.S.C.A. \$15c (Supp. 1978).

23. United States v. National Association of Real Estate Boards, 339 U.S. 485, 490-91, (1950).

24. U.S. Const. art I, \$8, cl. 3 .

25. 15 U.S.C. $\$ \$ 1-2$ (1976).

26. United States v. South-Eastern Underwriters Assn., 322 U.S. 533, 558 (1944). See also Mandeville Island Farms, Inc., v. American Crystal Sugar Co., 334 U.S. 219, 234 (1948); United States v. Employing Plasterers Assn., 347 U.S. 186 (1954).

27. "Trade or Commerce" includes, for example, the professions (Goldfarb v. Virginia State Bar, 421 U.S. 773 (1975), furnishing news (Associated Press v. United States, 326 U.S. 1 (1945), and entertainment enterprises (United Sates v. Paramount Pictures, Inc., 334 U.S: 131 (1948).

28. E.g., 15 U.S.C. $\$ \$ 14,17,45$ (1976).

29. Note that Section Three of the Clayton Act, 15 U.S.C. \$15 (1976) is limited to arrangements related to the sale or lease of commodities. The reference does not define commerce, but rather identifies practices which may be actionable under the section. Section Three of the Clayton Act is discussed further in 4.4. of this report, at notes 261 et seq., infra.

30. 15 U.S.C. $\$ \$ 1-2(1976)$.

31. U.S. Const. art. I, \$8, cl. 3 .

32. E.g., Gibbons v. Ogden, 9 Wheat. l (U.S. 1824); National Labor Relations Board v. Jones \& Laughlin Steel Corp., supra note 8.

33. E.g., United States v. Socony-Vacuum Oil Co., supra note 8 at 223-24.

34. Hospital Building Co. v. Trustees of Rex Hospital, 425 U.S. 738, (1976).

35. E.g. United States v. American Building Maintenance Industries, 422 U.S. 271 (1975); Federal Trade Comm. v. Bunte Bros., 312 U.S. 349 (1941).

36. United States v. Northern Pacific Ry., 356 U.S. 1, 5 (1958).

37. 310 U.S. 150,221 (1940).

38. Board of Trade of the City of Chicago v. United States, 246 U.S. 231, 238 (1918).

39. 15 U.S.C. $\$ 2(1976)$.

40. United States v. E. I. du Pont de Nemours \& Co., 351 U.S. 377 (1956); United States v. Aluminum Co. of America, 148 F. 2d 416 (2nd Cir. 1945). 
41. United States v. Grinnell, 236 F. Supp. 244 (D.R.I. 1964), aff'd. except as to decree 384 U.S. 563 (1966).

42. "Horizontal" is generally used to describe activity that occurs at the same level in the distributional chain of a particular product or service.

43. See United States v. Trans-Missouri Freight Assn., 166 U.S. 290 (1897); United States v. Joint Traffic Assn., 171 U.S. 505 (1898).

44. 15 U.S.C. $\$ 1(1976)$.

45. E.g., Interstate Circuit, Inc. v. United States, 306 U.S. 208 (1939).

46. Compare Interstate Circuit, Inc. v. United States, supra, note 45, with Theatre Enterprises Inc. v. Paramount Film Distributing Corp., 346 U.S. 537 (1954).

47. E.g., U.S. v Socony-Vacuum Oil Co. 310 U.S. 150 (1940); Keifer-Stewart Co. v. Joseph E. Seagram \& Sons, Inc., 340 U.S. 211 (1951).

48. E.g., American Column \& Lumber Co. v. U.S. 257 U.S. 377 (1921); Sugar Institute, Inc. v. U.S. 553 (1936).

49. E.g., Fashion Originators' Guild of America v. Federal Trade Comm. 312 U.S. 457 (1941); Associated Press v. U.S. 326 U.S. 1 (1945).

50. U.S. v. Topco Associates, Inc. 405 U.S. 596 (1972); U.S. v. Sealy, Inc. 388 U.S. 350 (1967).

51. Even joint ventures with "legitimate objectives may have anticompetitive implications". E.g., Timken Roller Bearing Co. v. United States, 341 U.S. 593 (1951); U.S. v. Pan American World Airways, Inc. 193 F. Supp 18 (S.D.N.Y. 2961), rev'd on other grnds, 371 U.S. 296 (1963).

52. E.g.; price fixing (United States v. Socony Vacuum-Oil Co. supra, note 8); group boycotts (Fashion Originators' Guild of America v. Federal Trade Comm., 312 U.S. 457 (1941).

53. American Column \& Lumber Co. v. United States, 257 U.S. 377, 409-410 (1921).

54. "Vertical" is generally used to describe activity that occurs at different levels in the distributional chain of the same product or service.

55. "Franchise agreements between manufacturers and retailers frequently include [location restrictions] barring the retailers from selling franchised products from locations other than those specified in the agreements." Continental T.V., Inc v. GTE Sylvania 97 S. Ct. 2549, 2551 (1977).

56. See generally Continental T. V. v. GTE Sylvania, Inc., 97 S. Ct. 2549 (1977).

57. 15 U.S.C. \$1 (1976).

58. 15 U.S.C. $\$ 2(1976)$.

59. E.g., Continental 'T. V., Inc. v. GTE Sylvania, Inc., supra, note 56.

60. White Motor Co. v. United States, 372 U.S. 253 (1963).

61. See United States v. Colgate \& Co., 250 U.S. 300 (1919).

62. United States v. Parke, Davis, and Co., 362 U.S. 29 (1960).

63. Otter Tail Power Co. v. United States, 410 U.S. 366 (1973). See also text at notes 39-4l, supra. 
64. 15 U.S.C. $\$ 18$ (1976). S. 600 ("The Small Business Protection Act") was introduced by Senator Kennedy in the 96 th Congress. The proposal seeks to prohibit mergers between companies with over two billion dollars. The measure would also restrict mergers and acquisitions by firms worth over 350 million dollars by requiring them to prove it would enhance competition. See Antitrust \& Trade Reg. Rep. (BNA) A$13(3 / 15 / 79)$.

65. E.g., United States v. Marine Bancorporation, Inc., 418 U.S. 602 (1974); BOC International v. Federal Trade Comm., 557 F. 2d 24 (2d Cir. 1977).

66. Although such a presumption has not been expressly stated, it is readily inferable from judicial opinions regarding vertical mergers. See, e.g., United States v. E. I. du Pont de Nemours \& Co., 353 U.S. 586 (1957); Ford Motor Co. v. United States, 405 U.S. 562 (1972); United States v. Standard Oil Co. (Potash), 253 F. Supp. 196 (D.N.J. 1966); Reynolds Metals Co. v. Federal Trade Comm., 309 F. 2d 223 (D.C.

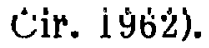

67. E.g. Brown Shoe Co. v. United States, 370 U.S. 294 (1962).

68. Northern Sec. Co. v. United States, 193 U.S. 197 (1904); United States v. Union Pacific R. R. Co., 226 U.S. 61 (1912).

69. United States v. General Dynamics Corp., 415 U.S. 486 (1974); United States v. Marine Bancorporation, Inc., 418 U.S. 602 (1974); United States v. Citizens \& S. National Bank, 422 U.S. 86 (1975).

70. 15 U.S.C. $\$ 17$ (1976).

71. Brown Shoe Service Co. v. United States 370 U.S. 294 (1962); United States v. Von's Grocery Co., 384 U.S. 270 (1966); United States v. Pabst Brewing Co., 384 U.S. 546 (1966).

72. See cases cited in note 65 , supra.

73. Id.

74. Federal Trade Comm. v. Consolidated Foods Corp., 380 U.S. 582, 594-595 (1965).

75. Determination of the relevant market is also critical to analysis of "tying arrangements" (wherein the seller requires that a customer who purchases product A must also purchase product B). Tying arrangements are discussed infra at text following nules 260 el sey.

76. United States v. E.I. du Pont de Nemours \& Co., 351 U.S. 377 (1956).

77. See Telex Corp v. International Business Machines, 510 F. 2d 894 (10th Cir. 1975).

78. U.S. v. Addyston Pipe \& Steel Co. 85 F. 271 (6th Cir. 1898), modified and aff'd, 175 U.S. 211 (1899).

79. See U.S. v. Alcoa 148 F. 2d 416 (2d Cir. 1945)

80. "Pooling arrangement" describes an agreement between two or more utilities to interconnect their systems for two-way exchanges of power.

81. S. 489, 94th Cong., 1st Sess. (1975).

82. E.g., H.R. 1564, H.R. 3166, H.R. 6512, H.R. 7816, H.R. 8573, and H.R. 8574, 95th Cong., lst Sess. (1977). 
83. E.g., Hearings on S. 409 Before the Subcomm. on Antitrust and Monopoly of the Comm. on the Judiciary, U.S. Senate, 94th Cong., 1st Sess. (July 14, 1975) (remarks and questions of Senator Abourezk).

84. Cf. FTC, Concentration Levels and Trends in the Energy Sector of the U.S. Economy (1974).

85. J. Markham, A. Hourihan, F. Sterling, Horizontal Divestiture and the Petroleum Industry, xxiii (1977).

86. One typically measures concentration levels in a given industry by comparing the aggregated sales volume of the 4 or 8 companies whose sales figures are highest to the aggregated sales volume for the entire market. A four-firm concentration ratio of $50 \%$ means that 4 firms account for one-half of the total sales in that industry.

87. Horizontal Divestiture and the Petroleum Industry, supra note 85 at 5 . The three authorities quoted by Harkham, Hourihan, and Sterling are: (1) J. Bain, Industrial Organization, 135-36 (2nd ed., 1968); (2) C. Kaysen and D. Turner, Antitrust Policy: An Economic and Legal Analysis, 98099 (1959); and (3) The Report of the White House Task Force on Antitrust Policy, [The Neal Report] at A-8, as reported in 1 J. of Reprints for Antitrust L. \& Econ., 720 (winter, 1969).

88. Id.

89. Id. at xxiv.

90. Id.

91. Otter Tail Power Co. v. United States, 410 U.S. 366 (1973); Cantor-Selden v. Detroit Edison Co., 428 U.S. 579 (1976). (Cantor-Selden).

92. 42 U.S.C. 2135 (as amended in 1970).

93. Prelicensing Antitrust Review of Nuclear Powerplants: Hearings on S.212, H.R.8289, H.R.9647, S.1883, and S.2768 before the Joint Committee on Atomic Energy Congress of the United States, 91st Cong., lst \& 2d Sess (1969-1970).

94. 42 U.S.C. 2135 (1976).

95. 15 U.S.C. $\$ 18$ (1976). U.S. v. Penn-Ulin Chemical Co.,378 U.S. 158 (1964) is the leading case on joint ventures under Clayton $\$ 7$.

96. See e.g., Cantor-Selden, supra note 91; U.S. v. Western Electric Compan by, Inc. and American Telephone and Telegraph Co., [1956 Trade Reg. Rep.] (CCH) I 68,246 (D.N.J. 1956); Regulatory and Policy Problems Presented by the Interdependence of Computer and Communication Services and Facilities, 28 F.C.C. 2d 267 (1971); Use of the Carterfone Device in Message Toll Telephone Service, 13 F.C.C. $2 \mathrm{~d} \overline{420}$ (1968).

97. See note 1 .

98. Executive Office of the President, The National Energy Plan (April 29, 1977). See also Energy Research and Development Administration, A National Plan for Energy Research, Development, and Demonstration. 2 (1977).

99. These rounded percentages are based on DOE's solar budget for FY78 as reported in U.S. Department of Energy, Solar Energy/A Status Report 5 (June 1978) [hereinaf ter cited as Status Report of June 1978]. 
100. Id.

101. J. Bereny, Survey of the Emerging Solar Energy Industry, 269-334 (1977) [hereinaf ter cited as Emerging Solar Industry].

102. See text at notes $81-90$ supra.

103. See e.g., K. Bossong, The Case Against Private Utility Involvement in Solar/Insulation Programs (Citizens Energy Project, 1978); Producing Your Own Power: How to Make Nature's Energy Sources Work for You (C. Stoner ed. 1974); B. Commoner, "The Solar Transition," as reprinted in FTC Solar Symposium Proceedings (1978).

104. These statistics are based on raw data compiled in Emerging Solar Industry, supra note 101 at $302-15$.

105. See Fortune, May 8, 1989, at 295-96.

106. See text at notes 81-90 supra, and at 119 et seq, infra.

107. ERDA Definition Report: National Solar Energy Research, Development and Demonstration Program (1975).

108. Solar Heating and Cooling Demonstration Act of $1974 \$ 14,42$ U.S.C. $\$ \$ 5512$.

109. 15 U.S.C. $\$ 632$ (1976).

110. Program Summaries listing the various government contract awards are available from DOE.

111. E.g., McLean Trucking v. U.S. 321 U.S. 67 (1944).

112. See United States v. Borden Co., 308 U.S. 188, (1939).

113. Railroad President's Conference v. Noerr Motor Freight, Inc., 365 U.S. 127 (1961);

- United Mine Workers v. Pennington, 381 U.S. 657 (1965).

114. E.g., City of Lafayette v. Louisville Power and Light; 98 S.Ct. 1123 (1978); nlinvis Brick v. Illinois, 97 S.Ct. 2061 (1977).

115. Noerr, supra note 113 at 136,139 .

116. Id. 365 U.S. at 144 . For other exceptions to the Noerr doctrine see Anno., 17 A.L.R. Fed. 645, 650 (1973).

117. Compare George R. Whitten, Jr., Inc. v. Paddock Pool Builders, Inc., 424 F2d 25 (1st Clr.) cerl. Uelr. 400 U.3. 850 (1970) (nu immunity) with United Statc3 v. Johno Manville Corp., 259 F.Supp 440 (E.D.Pa. 1966). See also Security Free Door Co. v. Los Angeles County, 484 F.2d 1028 (9th Cir. 1973). Similarly, misrepresentations madc in a contractor's bid, or harassment aimed at deterring rival firms from submitting bids "cannot acguire immunity by seeking refuge under the umbrella of political expression." Californis Motor Transport Co. v. Trucking Unlimited, 404 U.S. 508, 513 (1972).

118. E.g., S. 2625, 95 th Cong., 2nd Sess (1978).

119. See 42 U.S.C. $\$ \$ 4331$ et seg.

120. Petroleum Company Involvement in Alternative Sources of Energy, Prepared at the request of Frank Church for the Subcommittee on Energy Research and Development of the Committee on Energy and Natural Resources, U.S. Senate, (Sept 1977) p. 334. 
121. The entry of nonenergy Fortune 500 companies into the SHAC market raises similar issues insofar as size contributes to dominance, and ultimately to industrial concentration. The significant distinction, and the one which observers argue calls for closer oversight of the energy companies, is the substitutability of solar energy for fossil fuels as compared with the distinct, albeit related, market served by an appliance manufacturer, for example.

122. United States v. Ford Motor Co. 405 U.S. 562, 568 (1972).

123. See Hiland Dairy v. Kroger Co. 274 F.Supp. 966 (E.D. Mo. 1967) aff'd. 402 F.2d 968 (8th Cir. 1968) Cert denied 395 U.S. 961 (1969).

124. See text supra at notes 39 et seq.

125. 351 U.S. 377 (1956).

126. Id.

127. 236 F. Supp 244 (D.R.I. 1964) Aff'd except as to decree, 384 U.S. 563 (1966).

128. 384 U.S. at 574.

129. Cross-elasticity refers to the extent to which small changes in the current price of one product affect demand for another product. If products are substitutes for each other, they will display positive cross-elasticity.

130. U.S. v. Grinell, supra note 127, F. Supp at 250 .

131. E.g., National Gas Policy Act of 1978 Supl 2 note 1.

132. Tampa Electric Co. v. Nashville Coal Co. 365 U.S. 320, (1961).

133. The installation and maintenance requirement is not probative of delineated geographic markets in and of itself because firms may assign or subcontract service arrangements to local dealers, but it bolsters the primary argument based on climatic considerations.

134. See generally F. Roach, S. Noll, S. Ben-David, L. Bickle and W. Schulze, Prospects for Solar Energy: The Impact of the National Energy Plan (1977) (LA-7064-ms) (informal report prepared for DOE). If SHAC, sellers exclude such regions from their sales territories, it follows that in the geographic markets in which SHAC systems are sold, natural gas will not be competitively priced and should not be included in the relevant product market. However, if a particular seller chooses to enter regions where natural gas is competitively priced, the product market for that region ought to include natural gas. Thus, for each geographic region, the product market may or may not include the natural gas alternative.

135. See e.g., American Tobacco v. U.S., 328 U.S. 781 (1946).

136. United States v. Friffith 334 U.S. 100, FN10 (1948).

137. See note 125 .

138. U.S. v. Alcoa 148 F.2d 416, 424 (2d.Cir.1945).

139. U.S. v. Columbia Steel Co. 334 U.S. 495,528 (1948).

140. E.g., Standard Oil v. United States 221 U.S. 1, 61 (1911); U.S. v. American Tobacco 221 U.S. 106 (1911); U.S. v. E.I. du Pont de Nemours \& Co. 357 U.S. 477 (1956); International Boxing Club One v. U.S. 358 U.S. 242 (1959); and U.S. v. Grinnell Corp. 384 U.S. 563 (1966). 
141. Hiland Dairy Inc. v. Kroger Co. 402 F.2d 968, 974 (8th Cir. 1968) Cert. denied, 395 U.S. 961 (1969); White Bag Co. v. International Paper Co., 1974-2 Trade Cas., Paragraph 75,188 (4th Cir. 1974).

142. U.S. v. Grinnell 236 F.Supp 244 (D.R.I. 1964) aff'd in part and remanded 384 U.S. 563 (1966).

143. 384 U.S. at 571 . The District Court in U.S. v. Grinnell, 236 F. Supp 244 (D.R.I. 1964), had indicated that defendants $85 \%$ market share established a presumption of monopolization which shifted the burden of disproving monopoly to the defendants. Id. at 257. Because Grinnell had consciously acquired and maintained monopoly power, the Supreme Court found it "unnecessary" to endorse the District Court's approach 384 U.S. at 576, fn. 7.

144. See text following note 106, supra.

145. See generally Fortune, May 8, 1978 at 295.

146. American Tobacco Co. v. United States 328 U.S. 781, 811 (1946); See U.S. v. E.I. du Pont de Nemours \& Co., 351 U.S. 377 (1956); Standard Oil Co. v. U.S., 221 U.S. 1 (19ii).

147. See IBM v. U.S. 298 U.S. 131 (1936).

148. Sce Otter Tail Power Co. v. U.S. 410 U.S. 366 (1973).

149. Pub. L. No. 94-435, 90 Stat 1383 (1976). See also, note 64, supra.

150. See generally Fortune, May 8, 1978 at 238-265.

151. See generally Fortune, May 8, 1978, at 295.

152. FTC v. Proctor \& Gamble 386 U.S. 568, 577 (1968).

153. 370 U.S. 294 (1962).

154. Id. at 325.

155. FTC v. Proctor \& Gamble 386 U.S. 568 (1967); Reynolds Metal Co. v. FTC.309 F.2d 223 (D.C.Cir. 1962); General Foods Corp., 69 F.T.C. 380 (1966), aff'd 386 F.2d 936 (3rd Cir. 1967), cert. denied 391 U.S. 919 (1968); United S. v. Kennecott Copper Corp. 231 F. Supp 95 (S.U.N.Y. 1966), aff'd per curiam 381 U.S. 414 (1965); U.S. v. Pennzoil Co., 252 F. Supp 696 (W.D.Pa 1965); Filtrol v. Slick Corp., 1970 Trade Cas., Paragraph 73,035 (C.D.Cal. 1969), aff'd per curiam, 428 F.2d 826 (9th Cir. 1970).

156. Brown Shoe Co. v. U.S. 370 U.S. at 326 .

157. Id. at 325 .

158. Id. at 336-337.

159. United States v. County National Bank of Bennington. 339 F. Supp 85 (D. Vt. 1972).

160. 1 Trade Reg. Rep. (CCH) Paragraph 4510 at 6883.

161. Id. at 6884.

162. 374 U.S. 321 (1963).

163. Id. at 362 (emphasis supplied).

164. Id. at 364-5. 
165. E.g., U.S. v. Von's Grocery 384 U.S. 270 (1966); and U.S.v. Pabst Brewing Co. 384 U.S. 546 (1966).

166. Fortune, May 8, 1978 at 296.

167. U.S. v. Von's Grocery 384 U.S. 270, 278 (1966).

168. See note 105 , supra.

169. 394 U.S. 131 (1969).

170. Id: at 138 .

171. Id.

172. Id.

173. See id.

174. Union Leader Corp. v. Newspapers of New Eng., Inc. 284 F.2d 582 (lst Cir. 1960) cert. denied 365 U.S. 833 (1961); United States v. Maryland and Va. Milk Producers Assn. 167 F. Supp 799 (D.D.C. 1955) aff'd in part and rev'd in part, 362 U.S. 458 (1960); Grander v. Public Bank, 417 F.2d 75 (6th Cir. 1969) cert. denied, 397 U.S. 1065 (1.970).

175. U.S. v. Third Nat'l Bank in Nashville, 390 U.S. 171 (1968); U.S. v. Von's Grocery Co. 384 U.S. 270 (1966); United States v. Philadelphia National Bank (PNB) supra note 2; U.S. v. Diebold, Inc. 369 U.S. 654 (1962); United States Steel Corp v. FTC 426 F.2d 592 (6th Cir. 1970); Continental Oil Co. v. U.S. 393 U.S. 79 (1968).

176. See U.S. v. Penn-Olin Chemical Co., 378 U.S. 158 (1964) for complete listing of factors to be considered.

177. BOC International v. FTC 557 F.2d 24 (2d Cir. 1977).

178. U.S. v. Penn-Olin, supra note 176 .

179. BOC International v. FTC, supra note 177 .

180. 367 F. Supp. 1226 (C.D. Cal 1973), aff'd mem. 418 U.S. 906 (1974).

181. Kennecott Copper Corp. v. FTC, 467 F.2d 67 (10th Cir. 1972), cert. denied, 94 S.Ct. $1617(1974)$.

182. 1 Trade Reg. Rep. (CCH) Paragraph 4510 at 6888.

183. Id. at 6889 .

184. U.S. v. International Tel. \& Tel. Corp., 306 F. Supp 766 (D. Conn 1969) appeal dismissed per stipulation 404 U.S. 801 (1971).

185. Id. at 796-97.

186. U.S. v. Northwest Industries Inc. 301 F. Supp 1066, 1088 (N.D. IU 1969).

187. FTC v. Consolidated Foods Corp. 380 U.S. 592, 594 (1965).

188. Id. at 600 . See also U.S. v. ITT, 1971 Trade Cas., Paragraph 73,619 at 90,546 (N.D. Ill 1971).

189: R. Noll, "Maintaining Competition in Solar Energy Technology."

190. City of Lafayette v. Louisiana Power and Light (LPL) 98 S.Ct. 1123 (1978).

191. See text supra at notes 113 et seq. 
192. 317 U.S. 338 (1943).

193. Id. at 360 .

194. Id.

195. Cantor-Selden, supra note 91 at 592.

196. E.g., no antitrust immunity conferred by state authorization (Northern Securities v. U.S., 193 U.S. 197, 346) approval (Parker v. Brown, supra note 192 at 35l), encouragement (Goldfarb v. Virginia State Bar, 421 U.S. 773, 791) or participation (Continental Ore Co. v. Union Carbide, 370 U.S. 690).

197. Jackson v. Metro Edison, 419 U.S. 345 (1974).

198. U.S. v. PNB, supra note 5 .

199. California v. FPC 369 U.S. 482,485 (quoted with approval in U.S. v. Otter Tail supr'a note 91 at 1027 ).

200. Cantor-Selden supra note 91 at 598.

201. Id.

202. U.S. v. RCA 358 U.S. 334 (1959).

203. E.g., Hughes Tool Co. v. TWA Inc. 409 U.S. 363 (1973); Pan Am World Airways Inc. v. U.S. 371 U.S. 296 (1963); Scroggins v. Air Cargo Inc. 1974-2 Trade Cas., Paragraph 75,441 (N.D. Ga. 1974).

204. Ricci v. Chicago Mercantile Exchange 409 U.S. 289 (1973); Chicago Merc. Exch. v. Deaktor 414 U.S. 113 (1973); U.S. v. Western Pac. R.R. 352 U.S. 59 (1956).

205. Utah Pub. Serv. Comm. v. El Paso Nat'l Gas Co. 395 U.S. 464 (1969); Cascade Nat'l Gas Corp. v. El Paso Nat'l Gas Co. 386 U.S. 129 (1967); U.S. v. El Paso Nat'l Gas Co. 376 U.S. 651 (1964).

206. Industrial Communications Sys., Inc. v. Pacific Tel \& Tel. Co. 505 F.2d 152 (9th Cir. 1974).

207. Ricci v. Chicago supra note 204 at 306.

208. See cases cited in notes 201,202 , and 203 .

209. Cantor, supra note 91.

210. 15 U.S.C. $\$ 2(1976)$.

211. 15 U.S.C. \$14. (1976).

212. Regulated rates for public utility service are generally governed by the costs of service. These costs, when aggregated, form a "basis" from which reasonable ratcs may be computed.

213. Cantor, supra note 91 at FN 36 (plurality); Id. at 3128 (Blackmun, J. concurring).

214. Id. at 595-596 (Stewart, J. dissenting, criticized assertion as only applicable to federal statutcs).

215. This was suggested but never articulated by the concurring opinion of Chief Justice Burger, Id. at 604 .

216. PUC v. United Fuel Gas Co. 317 U.S. 456 (1943); FPC v. Nat'l Gas Pipeline Co. of AM 315 U.S. 575 (1942); Morgan v. U.S. 298 U.S. 468 (1963); and Rocky Mtn. Airways Inc. v. Colo. PUC 181 Colo. 170509 P.2d 804 (1973). 
217. It is interesting to note that if fluorescent and high intensity bulbs were included, the market share drops to $25 \%$.

218. E.g., U.S. v. Aluminum Co. of Amer. 148 F.2d 416, 431-32 (2d Cir. 1945); Lessig v. Tidewater Oil Co., 327 F.2d 459 (9th Cir.) cert. denied, 377 U.S. 993 (1964); Union Carbide \& Carbon Corp. v. Nisley, 300 F.2d 561 (10th Cir. 1961), cert. dismssd, 371 U.S. 801 (1962); Mt. Lebanon Motors, Inc. v. Chrysler Corp., 283 F. Supp 453 (W.D.Pa. 1968), aff'd per curiam 417 F.2d 622 (3d Cir. 1969).

219. E.g., Agrashell, Inc. v. Hammons Prods. Co., 479 F.2d 269 (8th Cir. 1973), cert. denied 414 U.S. 1032 (1973); Panotex Pipeline Co. v. Phillips Petroleum Co., 457 F.2d 1279 (5th Cir.), cert. denied 409 U.S. 845 (1972).

220. Grand Caillou Packing Co., 65 FTC 799 (1964) (Commissioner Elman, concurring), enforced sub. nom. La Peyre v. FTC 366 F.2d 117 (5th Cir. 1966).

221. . P. Areeda, Antitrust Analysis, 258 (Little, Brown and Co. 1974).

222. United Shoe v. United Shoe Machinery Corp., 110 F. Supp 295 (D. Mass. 1953) aff'd per curiam, 347 U.S. 521 (1954).

223. New construction, of course, would obviate the need for retrofitting and the systems' cost would be included in the total price of the building.

224. See note 1 supra.

225. E.g., Colorado.

226. E.g., Uniform Consumer Credit Code (reprinted in Consumer Credit (CCH) 11/12/74); U.C.C. Art. 9 (as amended in 1971).

227. The task of establishing a rate structure is ordinarily left to the discretion of utility management, however, the commission, through its rate oversight function, has the power and responsibility to approve rates only if they are lawful and reasonable.

228. Parker v. Brown supra, note 192.

229. Cantor-Selden supra, note 91 .

230. Northern Pacific Rail way Co. v. U.S. 356 U.S. 1 (1958).

231. See International Salt Co. v. U.S., 332 U.S. 392 (1947); International Business Machines Corp. v. U.S., 298 U.S. 131 (1936).

232. See text supra at note 230 .

233. U.S. v. Grinnell Corp., 384 U.S. 563 (1966); U.S. v. American Tobacco Co., 221 U.S. 106 (1911); Ovitron Corp. v. General Motors, 295 F. Supp 373 (S.D.N.Y. 1909); and U.S. v. Great A+l \& Pac. Tea Co., 67 F. Supp 626 (E.D. Ill. 1946) aff'd 173 F.2d 79 (7th Cir. 1949).

234. See text supra at notes 197 et seq.

235. U.S. v. ALCOA, 148 F. 2d. 416 (2d. Cir. 1945).

236. United States v. United Shoe Machinery Corp., 110 F. Supp 295 (D. Mass. 1953), aff'd per curiam 347 U.S. 521 (1954).

237. Jackson v. Metro Edison, 419 U.S. 345, quoted with approval in Cantor Selden v. Detroit Edison Co., 428 U.S. 579 at 594, FN 31.

238. See text supra at notes 201 et seq. 
239. 341 U.S. 384 (1957).

240. Id. at 389 .

241. 428 U.S. 579 (1976).

242. Id. at 596 n. 36 (plurality), 612-613 (Blackmun, J. concurring).

243. Id. at 594-595 (plurality),614 n. 6 (Blackmun, J. concurring).

244. Id. at 604.

245. See Id. at 622-623 (Stewart, J. dissenting). See also Legis. history of Sherman Act, H.R. Rep. No. 1707, 51st Cong., lst Sess. (1890); Northern Pacific Railway, supra note 230 at 4 .

246. U.S. Const. Amend. XI; Merrill Lynch, Pierce Fenner \& Smith, Inc. v. Ware, 414 U.S. 117 (1973).

247. E.g., Dean Milk Co. v. Madison, 340 U.S. 349 (1951).

248. See Cantor-Selden, supra note 241 at 611-614.

249. Id. at 627 (Stewart, J. dissenting).

250. U.S. v. E.I. du Pont de Nemours \& Co., 366 Ü.S. 316,327 (1961).

251. See note 250 supra and accompanying text.

252. See U.S. v. Bausch \& Lomb Optical Co., 321 U.S. 707 (1944).

253. 250 U.S. 300 (1919).

254. Id. at 308 .

255. E.g., U.S. v. OtterTail Power Co., 354 F. Supp 54 (D. Minn. 1971), aff'd in part and vacated and remanded in part, 410 U.S. 366.

256. See note 149 supra and accompanying text.

257. E.g., Standard Oil Co. of N.J. v. U.S., 221 U.S. l (1911); and U.S. v. American Tobacco Co., 221 U.S. 106 (1911).

258. See Grand Caillou Packing Co., 65 FTC 799 (1964) enforced in part sub nom, LaPeyrev. FTC 366 F.2d 117 (5th Cir. 1966).

259. See cases cited in note 233 supra.

260. Union Camp Corp. [1967-1970 Transfer Binder] Trade Reg. Rep., Paragraphs 18, 669 (FTC 1969); GAF Corp. [1967-1970 Transfer Binder] Trade Reg. Rep., Paragraphs 18, 694 (FTC 1969); Chase Bag Corp. [1967-1970 Transfer Binder] Trade Reg. Rep., Paragraphs 18, 758 (FTC 1969); Waugh Equip. Co., 15 FTC 232 (1931); Mechanical Mfg. Co., 16 FTC 67 (1932); California Packing Corp., 25 FTC 379 (1937).

26 1. Compare Helvey v. Wabash County REMC, 10 UCC Rep. 331 (1972) with Buckeye Union Fire Insurance Co. v. Detroit Edison Co., 10 UCC Rep. 977 (1972).

262. Standard Oil Co. v. U.S. 337 U.S. 293, 305-06 (1949) See also United Shoe Mach. Corp. v. United States, 258 U.S. 451 and cases cited in note 234 supra.

263. 345 U.S. 594 (1953).

264. Id. at 608-09 (emphasis in original). 
265. Colorado Pump \& Supply Co. v. Febco, Inc., 472 F.2d 637 (10th Cir.) cert. denied 411 U.S. 987 (1973); Carlson Co. v. Sperry \& Hutchinson Co., 374 F. Supp 1080 (D. Minn. 1973).

266. See Ungar v. Dunkin Donuts of America, Inc., 1976-1 Trade Cas $\$ 60,763$ at 68, 292 n. 7a (3d Cir. 1976), cert. denied 97 S.Ct. 74 (1976); Sulmeyer v. Coca Cola Co., 515 F.2d 835 (5th Cir. 1975), cert. denied 424 U.S. 934 (1976).

267. U.S. v. Loew's Inc., 371 U.S. 38, 49 (1962).

268. See note 38 supra and accompanying text.

269. Compare Webster County Memorial Hospital, Inc. v. United Mine Workers of Am. Welfare \& Retirement Fund of 1980, 536 F.2d 419 (D.C. Cir. 1976), with Virginia Excelsior Mills, Inc. v. FTC, 256 F.2d 538 (4th Cir. 1958); U.S. v. American Smelting \& Refining Co., 182 F. Supp 834 (S.D. N.Y. 1960).

270. 187 F. Supp 545 (E.D. Pa. 1960) aff'd per curiam 365 U.S. 567 (1961).

271. Id. at 556 .

272. Id. at 557,556 .

273. Id. at 557,560 .

274. Moore v. Mead's Fine Bread Co., 348 U.S. 115 (1954); Food Basket Inc. v. Albertsons's Inc., 383 F.2d 785 (10th Cir. 1967).

275. 419 U.S. 186 (1974).

276. Id. at 200,201 .

277. See note 261 .

278. The courts have consistently confined application of the Act to tangibles. E.g. Export Liquor Sales, Inc. v. Ammex Warehouse Co. 426 F. 2d 251 (6th Cir. 1970) cert. denied, 400 U.S. 1000 (1971) (Act not applicable to leases of realty); T.V. Signal Co. v. American Tel \& Tel Co., 462 F. 2d 1256 (8th Cir 1972) (Act not applicable to the lesing of space for cable TV wires on telephone poles). The same result follows where an incidental transfer of a tangible item is involved. e.g., TriState Broadcasting Co. v. United Press Int'l Inc; 369 F. 2d 268 (5th Cir 1966) (transfer of right to broadcast news, including incidental transfer of tangible news reports).

279. U.S. v. Griffith, supra note 136 .

280. 15 U.S.C. $\$ 633$ (1976).

281. 15 U.S.C. $\$ 632$ (1976).

282. 42 U.S.C.A. $\$ 5801$ (d) (1976).

283. SHACDA, supra note 108.

284. Legal Barriers, 145 (March 1978).

285. Solar Energy Intelligence Report, 2 (Nov. 7, 1977).

286. Legal Barriers, 151 (March 1978).

287. See text preceding note 148 , supra.

288. 35 U.S.C.A. $\$ 101$ (1976).

289. 35 U.S.C.A. \$102 (Supp., 1978). 
290. Anderson's-Black Rock, Inc. v. Pavement Salvage Co., Inc., 396 U.S. 57 (1969); Graham v. John Deere Co., 383 U.S. 1 (1966).

291. See Brenner v. Manson, 383 U.S. 519 (1966).

292. 35 U.S.C.A. $\$ 154$ (Supp., 1978).

293. 35 U.S.C.A. $\$ 112$ (Supp., 1978).

294. U.S. Const. art I, \$8, cl.8.

295. 35 U.S.C.A. $\$ 261$ (Supp., 1978).

296. See W. Bowman, Patent and Antitrust Law (1973).

297. Morton Salt Co. v. G.S. Suppiger Co., 314 U.S. 488, 493-94 (1942).

298. Mercoid. Corp. v. Mid-Continent Investment Co., 320 U.S. 661 (1944).

299. See cases cited in note 43 supra.

300. 15 U.S.C. $\$ 638$ (d).

301. Small Business Mobilization Act of 1942, Ch. 404, $\$ 11,56$ Stat. 357 (no longer in force).

302. See U.S. v. Line Material Co. 333 U.S. 287, 310 (1948); Maple Flooring Manufacturers Assn v. U.S. 268 U.S. 563 (1925).

303. See text accompanying note 321 et seg. infra.

304. 288 U.S. 344,360 (1933).

305. Id. at 359 .

306. Id. at 360 .

307. E.g., U.S. v. Topco Associates, 405 U.S. 596 (1972); U.S. v. Sealy, Inc., 388 U.S. 350 $(1967)$ \} U.S. v. Socony, supra notc 8.

308. E.g., U.S. v. Morgan, 118 F. Supp. 621 (S.D. N.Y. 1953); Associated Press v. U.S., 326 I.I.S. 1 (1945).

309. Compare United States. v. Automobile Mfgrs. Assn., 307 F. Supp. 617 (D.C. Cal. 1969), aff'd per curiam sub nom.; City of New York v. U.S., 397 U.S. 248, 90 S.Ct. 1105,25 L.Ed 2d, 280 (1970); U.3. v. Mrgl's. Aircraft Assoc., 1976-1 Trade Cas. $\$ 60,810$ (S.D.N.Y. 1975); In re Motor Vehicle Air Pollution Control Equip., 52 F.R.D. 398 (C.D. Cal: 1970), aff'd in part and rev'd in part, 481 F.2d 122 (9th Cir. 1973), cert. denied, 414, U.S. 1045, on remand; In re Multidistrict Vehicle Air Pollution, 1973-2, Trade Cas. $\$ 74,819$ (C.D. Cal, 1973) (no antitrust violation).

310. See text accompanying note 38 , supra.

311 . Sullivan, supra note 3 at 298 .

312. Id. at 299.

313 . Id.

314 . Id. at 300 .

315 . Id.

316. Id.

317. See text accompanying notes 87,88 , and 160 for suspect combined market shares. 


\section{42 U.S.C.A. \$5908 (1976).}

319. Id. By granting a license the patentee shares the monopoly.

320. Id.

321. See generally United States v. U.S. Gypsum Co., 333 U.S. 364 (1948); HartfordEmpire Co. v. U.S., 323 U.S. 386 (1945); Associated Press v. U.S., supra note 308; U.S. v. Terminal R.R. Assn., 224 U.S. 383 (1912); Gamco Inc. v. Providence Fruit \& Produce Bldg., Inc., 194 F.2d 484 (1st Cir. 1952) cert. denied 344 U.S. 817 (1952); Honeywell Inc. v. Sperry Rand Corp., 54 F.R.D. 593 (D. Minn. 1973).

322. Compare Industrial Machine Tool Co. v. Miami Window Corp., 234 F.2d 301 (5th Cir. 1956); Brownwell v. Ketcham Wire \& Mfg. Co., 211 F.2d 121 (9th Cir. 1954); U.S. v. Parker Rust-Proof Co., 61 F.Supp. 805 (E.D. Mich. 1945).

323. U.S. v. Glaxo Group Ltd., 410 U.S. 52, 64 (1973).

324. E.g., U.S. v. General Motors, 1965 Trade Cas Paragraph 71,624 (E.D. Mich. 1965); U.S. v. Western Electric Co., 1956 Trade Cas. Paragraph 68,246 (D.N.J. 1956).

325. E.g., Associated Press v. U.S. 326 U.S. 1 (1945).

326. See text accompanying note 53 .

327. U.S. v. Northern Pac. Ry, note 36, supra.

328. 310 U.S. 150 (1940).

329. Id. at 221 .

330. Id.

331. United States v. Container Corp. of America, 393 U.S. 333 (1969). Although this case has not been overruled, the courts seem to be moving towards a liberalized approach regarding price sensitive activities, e.g., U.S. v. General Motors Corp., 1974-2 Trade Cas. \$75, 253 at 97, 671 (E.D. Mich. 1974).

332. E.g., Fashion Originators' Guild of America v. FTC 312 U.S. 457 (1941).

333. A combination-wielding monopoly power is judged by monopoly standards. See text accompanying note 40 supra.

334. See note 52 .

335. SEIR, 2 (Nov. 7, 1977). Figure reported by SEIA spokesperson.

336. Sullivan, supra note 3 at 268 .

337. E.g., Cantor-Selden, supra note 244; Louisiana Power \& Light, supra note 114.

338. The discussion which follows regarding the government's position is taken from an article written by Mr. John $\mathrm{H}$. Shenefield, Assistant Attorney General, Antitrust Division, U.S. Department of Justice, entitled "Standards for Standards Makers," ASTM Standardization News, 8 (August 1978).

339. Id. at 9.

340. In U.S. v. Johns-Mansville Corp., 259 F.Supp. 440 (E.D. Pa. 1966); 1967 Trade Cases $\$ 72,184$ (E.D. Pa. 1967), The American Society for Testing and Materials (ASTM) was an unindicted co-conspirator charged with conspiring to restrain trade and fix prices. ASTM is a nonprofit scientific organization formed for the purpose of promuling knowledge of the materials of engineering and standardizing specifications and methods of test. After the Johns-Mansville trial, (in which the 
Corporation was acquitted), ASTM filed its request to clear the Society of any implication in its being named a co-conspirator. The Court exonerated ASTM, and its conclusions of law specifically recognized that $\Lambda$ STM's procedures afford due process and adequate representation. Regarding an appeals mechanism, the Court is silent.

341. Shenefield, supra note 338 at 10 .

342. See generally Cantor Selden, supra note 244 .

343. See generally LPL, supra note 114 .

344. E.g., Radiant Burners v. Peoples Gas Light \& Coke Co., 364 U.S. 656 (1961) (excluding competitors); C-O-Two Fire Equipment Co. v. U.S., 197 F.2d 489 (9th Cir.) cert. denied 344 U.S. 892 (1952) (conspiracy to fix prices); National Macaroni Manufacturers Assn. VFIC, 345 F.2d 421 (7th Cir. 1965) (control production); Roofire Alarm Co. v. Underwriters Laboratories, 188 F. Supp. 753 (E.D. Tenn. 1959), aff'd per curiam 284 F.2d 360 (6th Cir. 1960) (internal corporate operation).

345. See notes $160,161,182,183,351-53$ supra and accompanying text.

346. See text following note 310 , supra.

347. E.g., U.S. v. Von's Grocery Co. 384 U.S. 270 (1966); U.S. v. Pabst Brewing Co. 384 U.S. 546 (1966); U.S. v. Aluminum Co. of America (Rome Cable) 377 U.S. 271 (1964).

348. U.S. v. PNB, supra note 2 at 363 .

349. 384 U.S. 270 (1966).

350. Id. at 281 (White, J., concurring).

351. 1 Trade Reg. Rep. $(\mathrm{CCH})$ Paragraph 4510 at 6884. See text accompanying note 160 , supra.

3.5?. IT,

353. Id. 'I he trend is established if in any period of from five to ten ycars the leading firms have increased their aggregate share by $7 \%$ or more.

354. Emerging Solar Industry, supra note 116, at 269-334.

355. See note 105 , supra.

356. U.S. v. PNB supra note 2. 


\begin{tabular}{|c|c|c|c|}
\hline $\begin{array}{c}\text { Document Control } \\
\text { Page }\end{array}$ & $\begin{array}{l}\text { 1. SERI Report No. } \\
\text { TR }-62-27.2\end{array}$ & 2. NTIS Accession No. & 3. Recipient's Accession No. \\
\hline \multicolumn{3}{|l|}{ 4. Title and Subtitle } & 5. Publication Date \\
\hline \multirow{2}{*}{\multicolumn{3}{|c|}{$\begin{array}{l}\text { Impact of the Antitrust Laws on the Commercialization of } \\
\text { Solar Heating and Cooling }\end{array}$}} & \\
\hline & & & 6. \\
\hline \multicolumn{3}{|l|}{ 7. Author(s) } & 8. Performing Organization Rept. No. \\
\hline Jil1 G & ross & & \\
\hline & 9. Performing Organization Name and Address & & $\begin{array}{c}\text { 10. Project/Task/Work Unit No. } \\
6223.20\end{array}$ \\
\hline \multicolumn{3}{|c|}{$\begin{array}{l}\text { Solar Energy Research Institute } \\
1536 \text { Cole Boulevard } \\
\text { Golden, Colorado } 80401\end{array}$} & $\begin{array}{l}\text { 11. Contract (C) or Grant (G) No. } \\
\text { (C) } E G-77-C-01-4042 \\
\text { (G) }\end{array}$ \\
\hline \multicolumn{3}{|c|}{ 12. Sponsoring Organization Name and Address } & 13. Type of Report \& Period Covered \\
\hline & 14. \\
\hline
\end{tabular}

15. Supplementary Notes

16. Abstract (Limit: 200 words)

Many energy industry observers and solar equipment producers view the commercialization of solar technologies as an opportunity to undermine the dominance now enjoyed by energy companies and electric utilities. Whether their hopes will be realized depends on Congress! posture towards interenergy diversification (which is currently permissive), DOE's spending practives (which have, in the past, been relatively insensitive to competitive consequences), and ultimately, the Supreme Court's willingness to aggressively enforce the antitrust laws (which is not unlikely, given recent holdings). Notwithstanding the legislative and administrative branches' tacit compliance with entrenched firms' involvement in the various solar energy submarkets, injured business persons and consumers (as well as the Department of Justice and the Federal Trade Commission) have the opportunity to force the controversy onto the judiciary by bringing suit under the antitrust laws against companies allegedly displaying anticompetitive market practices. The interchangeability between end uses of renewable and nonrcncwable energy resources creates opportunities and motives for market manipulation. Consequently, the potential of energy firms for facilitating solar technology development (due to technolngical knowledge, managerial expertise and capital resources) must be weighed against the possibility that their involvement will, in the long run, retard development.

17. Document Analysis

a. Descriptors

b. Identifiers/Open-Ended Terríis

c. UC Categories

59

3. Availability Statement

\begin{tabular}{|l|}
$\begin{array}{l}\text { 19. No. of Pages } \\
70\end{array}$ \\
\hline $\begin{array}{c}\text { 20. Price } \\
\$ 5.25\end{array}$ \\
\hline
\end{tabular}

